\title{
DOCUMENTARIO
}

\section{Projeto n. 4.227, da Câmara dos Deputados - Institul o "Concurso Teixeira de Freitas", a ser realizado pelo I.B.G.E., com a participação do D.A.S.P., da A.B.M. e do M.E.C.}

\section{PROJETO N. $4.227-1958$}

Dispõe sôbre a Instituição e Organização do «Concurso Teixeira de Freitas»; estabelece as Bases da Participação do I. B. G. E. do D. A. S. P., do Minnistério da Educação e Cultura e da Associação Brasileira de Municipios na realização conjunta do referido Concurso; autoriza a abertura de crédito especial e dá outras providências.

\section{(Do $S r$. Souto Maior)}

(As Comissões de Constituição e Justiça, de Educação c Cultuta e de Finanças).

O Congresso Nacional decreta:

Art. $1^{\circ}$ Fica instituido e organizado o "Concurso Teixeira de Freitas" a ser realizado pelo Instututo Lisasileiro de Geografia e Estatisti.. (I.B.G.E.) com a participação da Associação Brasileira de Municipios (A.B.M.), do Departamento Admınistrativo do Serviço Público (D.A.S.P.) e do Ministério da Educação e Cultura. diais :

Art. 2: o "Concurso Teixeira de Freitas" tem como objetivos primor-

a) realizar um İquuérito de proporções nacionais tendo em vista um rigoroso levantamento dos problemas fundamentais dos Municipios brasileiros através da investrgação, pesquisa e análise técnico-científica, de suas condições atuais, necessidades e possibilidades;

b) formular, com base nos ciades c resultados do levaníaments efetuado, estudós concretos: sugestões pràticas ou projetos específicos em condições de serem encaminhados às autoridades federais, estaduais e municipais como contribuição ao exato equacionamento e solução objetiva dos referidos problemas ;

c) promover a análise, debate e divulgaçảo dos problemas de govêrno e administração municipal no âmbito das Universidades, Escolas Superiores, órgãos técnicos, institutos ou associações de cultura especializada, com a 
finalidade de despertar o interêsse de professôres e estudantes de nivel superior.

d) convocar os engenheiros, economistas, técnicos de administração, estatísticos, educadores, sociólogos e profissionais de nivel superior, em geral, para a pesquisa e estudo dos problemas fundamentais dos Municípios;

e) instituir os prémios "Calógeras", "Mauá" e "Euclides da Cunha" como estimulo aos pesquisadores, aos técnicos ou profissionais que apresentarem as melhores contribuicíses, projetos ou estudos especificos de interêsse para os Municípios brasileiros objetivando soluções concretas para os respectivos problemas fundarnentais ;

f) publicar os trabalhos, projetos ou estudos que forem selecionados, julgados e aprovados pela Banca Examinadora do "Concurso Teixeira de Freitas".

Art. 2: 0 "Concurso Teixeira de Freitas" compreende os seguintes Prêmius Especials :

I -.. Prêmio Calógeras - a ser atribuido aos trabalhos referentes a Organização e Administração do Municipio Moderno. Problemas situados no campo do Direito e da Administração Municipal em geral. Aspectos politicos, jurídicos e Administrativos da Operação Municipio, suas Projeç̃óes Regionais e Locais. Doutrinas e Técnicas da Descentralização. Colaboração Intergovernamental e Interadministrativa. Acôrdos e Convênios, Consórcios Intermunicipais.

II - Prêmio Mauá - para os trabalhos relativos à Economia e às Finan ras Municipais. Tributação. Orçamento. Investimentos. Empréstimos. Financiamentos. Coniabilidade. O Desenvolvimento Planificado dos Municipios. Planejamento Econômico-Social. Aspectos Econômicos, Financeiros e Sociais da Operação Município, suas Projeções Regionais e Locais.

III - Prêmio Euclides da Cunha - Urbanismo. Obras, Empreendidimentos e Serviços. Teoria e Prática dos Planos Diretores das Cidades. Formulação de Planos Globais. Os Aspectos Técnicos e a Exeqüibilidade do Sistema Geral da Operação Município, suas Projeções Regionais e Locais.

Art. 4" Além dos três Prêmios Especiais referidos no artigo anterior - Prêmios "Calogeras", "Mauá" e "Euclides da Cunha" - o Regulamento do "Concurso Teixcira de Freitas" poderá instituir outros prêmios de me:tor expressão financeira, para os trabalhos classificados em segundo lugar pela Ban:a Examinadora do Concurso.

Ari. 5? O "Concırso Teixeira de Freitas" será planejado, organizaco, administrado e executaío por uma Comissão Técnica que funcionará junto ao Instituto Brasileiro de Geografia e Estatistica.

Art. 6: A Comissão Técnica criada nos têrmos da presente Lei será constituida de sete menbros, sendo dois representantes do Instituto Brasileiro de Geografia e Estatística, dois da Associação Brasileira de Municipios, dois do Departamento Administrativo do Serviço Público e um do IMinistério da Educação e Cultura. 
Parágrafo único. Os Presidentes do Instituto Brasileiro de Geografia e Estatística e da Associação Brasileira de Municipios, o Diretor-Geral do Departamento Administrativo do Serviço Público e o Ministro de Estado da Educaçäo e Cultura designarão os representantes das respectivas Entidades, dentro de trinta dias, a partir da publicação da presente Lei.

Art. 7: O Instituto Brasileiro de Geografia e Estatística mobilizará tôdas as Agências Municipais de Estatística sob sua jurisdição, no sentido de promover' a mais ampla irradiação das atividades da Comissão Técnica do "Concurss Teixeira de Freitas" no território nacional e levar a efeito entendimentos imediatos coin as Prefeituras e Câmaras Municipais, a fim de asseguras o pleno êxito do referido Concurso.

Art. 8: O Departamento Administrativo do Serviço Público, por intermédio da sua Divisão de Orçamento e Organização, proporcionará tôdas as facilidades à Comissão Técnica do "Concurso Teixeira de Freitas", tendo em vista o planejamento e a execuçâo - conjuntamente com o I.B.G.E. o M.E.C. e a A.B.M. - do Inquérito Nacional previsto no item a, do art. 2 ? da presente Lei.

Parágrafo único. Os dados numéricos ou resultados do mencionado Inquérito servirão de base à elaboração de um Relatório e Projetos especificos a serem encaminhados pela Comissão Técnica, ao Presidente da República, tendo em vista :

a) melhor participação dos Municipios no Orçamento Geral da União:

b) sistematização e disciplina dos Acôrdos, Convênios e Ajustes Adminıstrativos ora em andamento nos diversos Ministérios e Órgãos Administrativos da União e referentes a problemas, assuntos e interêsse dos Municipios ;

c) suģestões e providências concretas visando à simplificação dis processos e à descentralização administrativa.

Art. 9* O Ministério da Educação e Cultura promoverá o entrosameuto da Comissão Técnica do "Concurso Teixeira de Freitas", com as Universidades, Escolas Superiores e demais Órgãos Técnicos ou culturais, tomando tôdas as medidas necessárias à convocação dos engenheiros, técnicos de administração, economistas, educadores, sociólogos, estatísticos e profissionais de nive: superior que deverão participar do "Concurso Teixeird de Freitas".

Parágrafo único. O Departamento de Administração e o Serviço de Documentação do Ministério da Educação e Cultura proporcionarão tôdas as facilidades à Comissão Técnica do "Concurso Teixeira de Freitas" nos assuntos de sua alçada, inclusive a utilização do Salão de Exposições e do Auditório do Edifício Sede do Ministério para as Sessões Solenes de Iulgamento e Apresentação dos trabalhos selecionados e premiados pelo "Concurso Teixeira de Freitas" consoante os dispositivos de seu Regulamento específico.

Art. 10. A Associação Brasileira de Municípios, além de participar da realização do "Concurso Teixeira de Freitas" em tôdas as suas fases, fica expressamente incumbida de divulgar, através de suplementos especiais do 
seu órgão oficial - o "ABM - Jornal" - os comunicados, as noticias, o andament.) geral das atividades da Comissão Técnica e os trabalhos premiados.

Art. 11. A Assuciação Brasileira de Municipios, em colaboração com a Agência Nacional do Ministério da Justiça e Negócios Interiores - para êste fim expressamente autorizada pela presente Lei, manterá permanente articulação com as Prefeituras, Câmaras Municipais, Universidades, Escclas Superiores, órgãos de Administração Federal, Governos Estaduais, Jornais e Rádioemissoras de todo o País, no que se refere à execução do "Concurso Teixeira de Fireitas", às iniciativas e atividades da respectiva Comissão Técnica.

Art. 12. Encerrado o julgamento, selecionados e premiados os trabalhos, estudos, projetos e demais contribuições técnicas do "Concurso Teixeira de Freitas" fica a Associaçâo Brasileira de Municípios encarregada de promover junto aos Podêres Constituídos, às Autoridades federais, Estaduais e Municipars, o andamento, a fiscalização e a execução das providências decorrentes do "Concurso Teixeira de Freitas".

Art. 13. A Comissão Técnica, instituída na forma dos arts. 5 e $6^{\text {? }}$ entrará em funcionamento imediato com a designação dos Membros que deverão constituí-la 30 dias após a publicação da presente Lei, e terá o prazo de 60 dias para elaborar o Regulamento do "Concurso Teixeira de Freitas", assim comc o Regimento Interno que disciplinará o seu próprio funcionamento.

Art. 14. A Comissão Técnica - integrada pelos sete Membros representantes dos órgãos co-participantes mencionados no art. 1\%, reunir-se-á obrigatòriamente uma vez por semana e, extraordinàriamente, sempre que convocada pelo seu Presidente.

Art. 15. A Comissão Técnica elegerá alternadamente, em cada reunião, o seu Presidente, consoante os dispositivos fixados a êsse respeito pelo Regimento Interno previsto no art. 13.

Art. 16. A Comissão Térnica organizará uma Secretaria Executiva incumbida de processar todo o expediente do "Concurso Teixeira de Freitas", tomar as medidas necessárias à concessão e pagamento dos Prêmios Especiais "Calógeras", "Mauá" e "Euclides da Cunha" e demais prêmios subsidiários; discriminar, aplicar e controlar os recursos próprios da Comissão Técnica (Art. 19, item I) : preparar o dossiê da comprovação das despesas efetuadas $e$ as prestações de Contas.

Parágrafo único. O Secretário Executivo da Comissão Técnica do "Concurso Teixeira de Freitas" será escolhido dentre os Membros integrantes da referida Comissão, simultâneamente com a eleição do respectivo Presidente.

Art. 17. A Comissão Técnica do "Concurso Teixeira de Freitas" é de natureza provisória, tendo o seu funcionamento condicionado à duração máxima de dois anos, contadós a partir da publicação desta Lei.

Parágrafo único. Encerrados os trabalhos de realização do "Concurso Teixeira de Freitas", o Secretário Executivo promoverá a liquidação de todos os encarg̣os e compromissos da Comissão Técnica, e a transferência do seu 
acervo à Associação Brasileira de Municípios a fim de que esta Entidade dê cumpriment, aos dispositivos do art. 12 desta Lei.

Art. 18. Fica o Poder Executivo autorizado a abrir, pelo Instituto Brasileiro de Geografia e Estatística (I.B.G.E. - Secretaria Geral de Administração), o crédito de $\operatorname{Cr} \$ 5.000 .000,00$ (cinco milhões de cruzeiros) para ocorrer as despesas do "Concurso Teixeira de Freitas".

Art. 19. O crédito a que se refere o artigo anterior será distribuido aos órgãos ou entidades rasponsáveis pelo planejamento, coordenação, organização e execução do "Concurso Teixeira de Freitas", da seguinte forma :

Cr\$

$3.000 .000,00$

$500.000,00$

$500,000,00$

$500.000,00$

$500.000,00$

$5.000 .000,00$

Art. 20. Os recurıos financeiros atribuidos à Comissão Técnica se destinam, em sua totalidade, ao pagamento e distribuição dos Prêmios Especiais "Calógeras", "Mauá" e "Euclides da Cunha" e demais prêmios instituidos pelo Regulamento do "Concurso Teixeira de Freitas". (Art. 19, item I).

Art. 21. As dotações consignadas à Secretaria-Geral de Administração do I.B.G.E., à Divisão de Orçamento e Organização do D.A.S.P., ao Serviço de Documentação do Ministério da Educação e Cultura e à Associação Brasileira de Municípios têm como finalidade ocorrer às despesas decorrentes da participação, dos compromissos e trabalhos das mencionadas entidades no que se refere ao planejamento, coordenação, organização e execução do "Concurso Teixeira de Freitas", de acôrdo com as atribuições especificas e responsabilidades que lhes são estabelecidas pela presente Lei.

$\S 18$ As despesas administrativas da Comissão Técnica serão descentralizadas e efetuadas diretamente pelas entidades que dela participam na proporçã: dos respectivos encargos, dentro dos quantitativos que lhe são atribuidos na forma dos itens II, III, IV e V do art. 19.

$\S 2$ A fim de assegurar o pleno funcionamento, a continuidade adminis. trativa, a eficiência e a coordenação técnica do "Concurso Teixeira de Freitas", fica automàticamente efetuado o destaque de $20 \%$ (vinte por cento) das dotações consignadas pelos itens II, III, IV e V, do art. 19, à Secretaria- Geral de Administração do I.B.G.E. à Divisão de Orçamento e Organização do D.A.S.P., no Serviço de Documentação do Ministério da Educação e Cultura e à Associação Brasileira de Municípios.

$\S 3$ \% O produto oriundo do destaque de $20 \%$ (vinte por cento) das dotaçōes referidas no varágrafo anterior (itens II, III, IV,e V, do art. 19) 
e no montante global de $\operatorname{Cr} \$ 400.000,00$ (quatrocentos mil cruzeiros), destina-se às despesas com o pagamento dos professôres ou membros da Banca Examinadora do Concurso; gratificações ao pessoal requisitado ou contratado; material de expediente e demais encargos burocráticos da Comissão Técnica.

Art. 22. O crédito especial aberto pelo art. 18 será automàticamente registrado ro Tribunal de Contas e distribuido ao Tesouro Nacional devendo os órgãos ou entidades beneficiárias prestar contas das importâncias recebidas na forma da Lei.

Art. 23. Se o crédito especial de que tratam os arts. 18 e 22 não fôr aberto, o seu quantitatiro global será incluido com a mesma destinação no primeiru Orçamento Federal que se elaborar.

Art. 24. Esta lei entrará em vigor na data de sua publicação, revogadas as disposições e mcontrário. Federal.

Sala das Sessões, em 26 de maio de 1958. - Souto Maior, Deputado

Senhor Presidente :

\section{Justificação}

Tenho a honra de submeter à alta deliberação do Congresso Nacional o Projeto de Lei anexo que dispõe sôbre a instituição e organização do 'Concurso «Teixeira de Freitas» a ser realizado conjuntamente pelo Instituto Brasileiro de Geografia e Estatística e pela Associação Brasileira de Municípios, com a mais ampla participação possivel do Departamento Administrativo du Serviço Público e do Ministério da Educação e Cultura.

2. Parece-me desnecessário acentuar a importância educativa, técnica e cultural do singular empreendimento sugerido pela Associação Brasileira de Municípios, como ponto de partida para realização de um Inquérito de proporções nacionais vinculado à investigação e análise dos problemas fundamentais de quase 2.500 Comunas cujas necessidades e reivindicações básicas, estão exigindo soluções urgentes, arrojadas e decisivas. Os referidos problemas têm sido, de resto, objeto de exaustivos e, por vêzes, profundos debates ao ensej: da realização periódica dos Congressos Nacionais e das inúmeras concentrações regionais de prefeitos e vereadores que, desde 1050 , se vêm realizando em todo o País, sob os auspicios da A.B.M.

3. Todavia, as experiências dêstes últimos anos, - no que se refere ao estudo e solução dos problemas de govêrno e administração municipal demonistrarn que é preciso entrosar o Movimento Municipalista brasileire com os órgãos técnicos mais ligados à pesquisa e estudo dêsses problemas, e. notadamente, com as Universidades, escolas superiores, instituições culturais e setores especializados da Técnica, do Ensino e da Cultura, em geral.

4. De fato, a liçâo dos últimos anos é no sentido de que urge promover uma articulação mais estreita e uma ampla integração dos nossos melhores eccnomistas, técnicos de administração, engenheiros, estatísticos, educadores, sociólogos e profissionais de nivel superior, com os problemas fundamentais 
dos Municipios, os quais devem ser objeto de permanente pesquisa e tratamento científico, inclusive nos estabelecimentos de ensino superior.

5. O "Concurso Teixeira de Freitas" - tal como formulado pelo então Secretário-Grela da A.B.M., Dr. Araújo CAVAlCÂNTI - contribuirá para erradicar, dentro de pouco tempo, a improvisação e o empirismo, no âmbito da investigação dos problemas municipais; estabelecerá bases mais sólidas à formulação das soluções técnicas e práticas que devem ser colimadas e pelas quais estão esperando as Prefeituras e Câmaras Municipais. de todo o Brasil ; finalmente, o "Concurso Teixeira de Freitas" convocará E reunirá as melhores inteligências e as mais autênticas capacidades profissionais para o estudio profundo dos problemas essenciais das Unidades elementares da Federação brasileira.

6. Devidamente estimuladas pelos prêmios a serem instituídos, é de se presumir que as melhores inteligências e capacidades do nosso Pais contribuam. com as suas pesquisas, trabalhos, estudos, projetos e sugestões para acelerar 0 ritmo do desenvolvimento geral dos Municipios, a modernização e aperfeiçoamento dos respectivos métodos de govêrno e administração - em sintese, para melhoria das condições gerais de vida, trabalho, cultura e bem-estar de todo o Brasil.

7. A proposta inicial da instituição do "Concurso Teixeira de Freitas remonta à reunião conjunta dos Conselhos Deliberativos, Diretor e Fiscal da A.B.M.; levada a efeito a 18 de janeiro de 1957. Coube ao Secretário-Geral da Entidade, o representante do Território do Rio Branco, Dr. Araújo CaVAlCÂNTI propor a realização dêsse empreendimento de âmbito nacional, como homenagem especial ao insigne brasileiro TeIXEIRA DE FreITAS - criador do nosso Sistema Geográfico-Estatístico-Censitário - que dedicou os seis últimos meses de sua vida ao estudo da Operação Municipio, suas Projeções Regionais e Locais, elaborando um substitutivo ao primitivo Projeto $n^{\circ} 4.614-54$ do Senador Jarbas Maranhão. A sugestão do representante do Território do Rio Branco foi aprovada por unanimidade, e transformada em Resolução pelos Conselhos reunidos da A.B.M., tendo início, então, os primeiros entendimentos com o Instituto Brasileiro de Geografia e Estatística acêrca das providências complementares e demais minúcias relativas à execução do magno Concurso.

8. Levada ao IV Congresso Nacional de Municipios, a Resolução da Associação Brasileira de Municípios foi objeto de Recomendação Especial, em virtude de seus altos objetivos como iniciativa de grande alcance destinada a proporcionar ao Movimento Municipalista um profundo sentido renovador de instrumento a Serviço da Técnica e da Cultura.

9. O referido Concurso compreende, entre outras providências de ampla repezcussão educacional e técnica, a criação de três Prêmios especiais denominados "Calógeras", "Mauá" e "Euclides da Cunha"., vinculados aos problemas fundamentais de Govêrno e Administração Municipal. Além dêstes, estão previstos prêmios subsidiários.

10. Levado a efeito sob os auspícios da Associação Brasileira de Municípios e do Instituto Brasileiro de Geografia e Estatística, devidamente 
articulados para êsse fim, - sem excluir a decisiva cooperação do Departamento Administrativo do Serviço Público e do Ministério da Educação e Cultura - o "Concurso Teixeira de Freitas" tem como finalidade primordial promover a modernização das técnicas, métodos e práticas governamentais e administrativas, em benetício das Prefeituras e Câmaras Municipais. Além do enquadramento dos municípios em um sistema de aperfeiçoamento gradual e rigorosa planificação, o "Concurso Teixeira de Freitas" proporcionará elementos indispensáveis à obtenção de soluções definitivas para as Comunas e contribuirá, subsidiàriamente, para estimular o desenvolvimento científico, técnico e cultural do País.

11. Os aludidos prêmios correspondem, em linhas gerais, aos seguintes Setores ou Grupos de problemas :

I - Prêmio Calógeras - Problemas de Organização e Administração do Municipio Moderno (Aspectos Jurídicos de Administração Municipal. O Município em face da Constituição e das Leis. As Leis Orgânicas das Municipalidades. O Regime das Cartas Próprias. A Divisão do Trabalho na Organizaçãu e na Administração do Municipio. O Prefeito e a Câmara dos Vereadores. Legislação e Ação Administrativa. Estrutura e Funciona. mento dos principais órgãos da Administração Municipal. Aspectos da Administração de Pessoal nos Municipios. Aspectos da Administração de Material nos Municípios. O Patrimônio Municipal. Regulamentação dos Serviços de Utilidade Pública. Serviços Municipais de Educação, Saúde e Assistência Social. O Municipio e os Problemas Municipais. O Contrôle Popular e Democrático das Administrações Municipais. Doutrinas e Técnicas da Descentralização. A Carta dos Municipios. A Operação Municipio, suas Projeções Regionais a Locais: - Aspectos Políticos, Administrativos, Econômicos, Financeiros, Técnicos e Culturais).

Il - Prêmio Mauá - Economia e Finanças Municipais (Tributação. Investimentos. Empréstimos. Financiamentos. Orçamento. Contabilidade. Desenvolvimento Planificado dos Municipios. Planejamento Econômico e Social. Discriminação de Rendas. Métodos. Princípios. O problema no Brasil. Perspectivas - Estudo comparativo da Discriminação de Rendas nas Constituições Brasileiras de 1891, 1934, 1937, 1946. Sistema Tributário Brasileiro: União, Estados e Municipios. Participação do Município em tributos federais e estaduais. Fundos Nacionais com aplicação especifica. Admınistraçãu Municipal. Tipos. Departamentos de Administração Geral. O órgâo central de Orçamento. Organização Financeira. O Orçamento. Principios gerais aplicáveis aos Municípios. Processos Orçamentários: elaboração, votação, execução, fiscalização. Programas de Trabalho. Normas financeiras e de contabilidade para os Municípios. Receita Pública. Classificação e Estimativa. Receita Municipal, Impostos e taxas. Despesas Públicas. Classificação e Estimativa. Despesas Municipal. Execução, Fiscalização e Contrôle do orçamento. Contrôle interno. Contrôle externo. Empenhos, reservas orçamentárias. Contrôle de pessoal, material, obras. Fisualização da receita. Custos. Divida Pública. Responsabilidades e Compromissos Municipais. Carta dos Municipios. Operação Municipio: 
- Projeções Regionais e Locais: Aspectos Políticos, Administrativos, Econômicos, Financeiros, Técnicos e Culturais).

III - Piêmio Euclides da Cunha - Urbanismo avançado. Obras, Empreenćimentos e Serviços. Teoria e Prática dos Planos Diretores das Cidades. Formulação de Planos Globais. A Operação Municipio. (Doutrinas e Técnicas modernas de Planificação. Órgãos e Serviços de Pesquisa e Planejamento. O Planejamento e a Cooperação Intergovernamentais. Consórcio e Convênios. Intarmunicipais. Ecologia. O Município e a Geografia Humana. Defesa dos Recursos Naturaıs. A Documentação e a Estatistica a Serviço do Planejamento. Urbanismo. Doutrina e Técnica, Códigos de Obras. Alguns problemas de base dos Municipios : saneamento, água, energia, esgotos, interligações rodoviárias e edifícios públicos. Obras Municipais. Aspectos técnicos e financeiros. Administração Planificada. O Sistema Geral da Operação Municipio, suas Projeções Regionais e Locais: - Aspectos Políticos, Econômicos, Financeiros, Técnicos e Culturais (arıa dos Municípios: Princípios, Direitos e Reivindicações).

12. A fim de garantir através do "Concurso Teixeira de Freitas" a concessão dos Prêmios "Cológeras", "Mauá" e "Euclides da Cunha" - e demais prêmios subsidiários - seria aberto crédito especial vinculado a cada um dos mencionados Setores ou Grupos de problemas.

13. $E$ ' inegável que o estabelecimento do "Concurso Teixeira de Freitas" determinará, em pouco tempo, um sério movimento cultural, principalmente nas escolas superiores de direito, engenharia, agronomia, administração, economia e finanças, estimulando as vocações universitárias para a investigação científica das soluções que os problemas fundamentais de quase 2.500 Comunas estão exigindo. Soluções de envergadura, técnicas, objetivas e decisivas.

- 14. Por outro lado, um Concurso dessa ordem fará convergir para o Movimento Municipalista as atenções, a simpatia e o respeito das classes universitárias - mestres e estudantes das nossas escolas superiores; reunirá técnicos e administradores em tôrno dos "Problemas de Base" do Brasil aos quais TeIXeIRA DE Freitas declarou sua nobre existência.

15. Efetivamente, se o Municipalismo deve sobreviver e ser transformado en uma poderosa fôrça a serviço da técnica e da cultura, urge reunir em tôrno dêsse sadio movimento os nossos melhores engenheiros, urbantstas, técnicos de administração, agrônomos, economistas, estatísticos, sociólogos, educadores e profissionais de nivel superior cujos conhecimentos e experiência possam contribuir para acelerar o ritmo de desenvolvimento geral dos Municipios. Com a realização do «Concurso Teixeira de Freitas» a A.B.M. e o I.B.G.E. conseguirão equacionar com exatidão, entre outros, os problemas vinculados ao subdesenvolvimento do Interior e o lamentável pauperismo das massas rurais, formulando, do mesmo passo, as soluções concretas e definitivas tão ansiosamente esperadas pelos Municípios brasileiros. Ao mesmo tempo, o "Concurso T'eixeira de Freitas" levará a efeito um Inquérito decrsivo para tormulação objetiva das soluções urgentes e práticas que o Interior reclama dentre as quais a Operação Municipio, com suas Projeções Regionais 
e Lncais, é apenas o prelúdio do que se poderá fazer de concreto, um delineamento prévio indicando o roteiro a seguir.

16. Encerrado o IV Congresso Nacional de Municipios aguardam as Preteituras e Câmaras Municipais o cumprimento das Recomendaçoes Ł demais trabalhos aprovados sôbre $v$ assunto. Por êste motivo cumpre promover, desde já, a mais ampla divulgação possivel das bases e condiçces do "Concurso Teixeira de Freitas" dentro dos seguintes princípios fundamentais :

a) só serão premiados trabalhos ou contribuições originais ;

b) os trabalhos submetidos a julgamento devem apresentar caráter de rigoroso espirito cientifico e extrema objetividade;

(:) os trabalhos devem versar sôbre os problemas constantes cos Setores os Grupos que estão vinculados aos respectivos prêmios ("Calógeras", "Mauá" e "Euclides da Cunha");

d) os trabalhos serão julgados por uma Banca Examinadora especial, integrada por professôres indicados pelo Ministério da Educação e Cultura, pelo Departamento Administrativo do Serviço Público, pelo Institutu Brası leiro de Geografia e Estatística e pela Associação Brasileira de Municípios ;

e) a Associação Brasileira de Municipios, o I.B.G.E., o Departamento Administrativo do Serviço Público e o Ministério da Educação e Cultura, designarão conjuntamente uma Comissão de sete (7) Técnicos credenciados pelos seus tituios universitários, curso superior no Brasil e no exterior, comprovada capacidade e tirocinio profissional, para os necessários entendimentos com as Universidades, administração dos recursos destinados aos Prêmios, elaboração do Regulamento Geral do Concurso e sua realização;

f) quanto aos pormenores relativos aos prazos, condições de inscrição, candidatos, constituição da Banca Examinadora, julgamento dos trabalhos e distribuição dos Prêmios êles serão exaustivamente tratados pelas Instrucñes Normativas ou Regulamento a ser organizado pela Comissão Técnica criada nos têrmos do Projeto de Lei anexo.

17. Basta uma iniciativa desta ordem, Senhor Presidente, para justificar a concessão pelo Govêrno dos recursos atribuidos aos Congressos Nacionais de Municipios. Trata-se de empreendimentos de incalculáveis repercussōes a curto prazo que virá consolidar, de maneira definitiva, o verdadeiro Municipalismo e salvá-lo das incursões demagógicas ou partidárias que ameaçam desacreditá-lo. A realização de um Concurso desta natureza contribuirá para enquadrar o Municipalismo no plano das mais altas preocupações culturais do Pais, estimular os técnicos e administradores de real capacidade profissional e imprimir ao Movimento Municipalista a orientação verdadeira, exata e superior que the deve ser dada.

18. Acresce ainda a circunstância de que a instituição do "Concurso Teixeira de Freitas" é uma providência concreta no sentido de serem plenamente realizados os objetos colimados pelos arts. $1^{\circ}$ e $2^{\circ}$ dos próprios Estatutos da Associação Brasileira de Municipios. (Art. 10: A A.B.M. é uma Sociedade Civil, de âmbito nacional, com sede no Rio de Janeiro, operando num regime de intima cooperação com as municipalidades, instituições conyêneres $e$ afins, bem assim com quaisquer entidades estaduais, federais $t$ internacionais. Art. 2: São objetivos especificos da A.B.M.: a) formular 
nas suas grandes linhas as diretrizes do Movimento Municipalista do país; b) promover o aperfeiçoamento da administração municipal na multiplicidade de seus aspectos; c) sugerir aos podêres competentes as medidas que the parecem oportunas e necessárias; d) realizar os objetivos de coopcração expostos nos Estatutos da Comissão Pan-Americana de Cooperação Intermunicipal, nas formas recomendadas e ratificadas pelos Congressos Pan-Americanos de Municípios e pela VI Conferência Internacional Americana; e) propugnar pela integral aplicação dos dispositivos consubstanciados na Carta de Principios, Direitos e Reivindicações Municipais e pelas Recomendações aprovadas nos Congressos Nacionais de Municipios brasileiros; f) promover, cada 2 anos, a realização dos Congressos Nacionais de Municipios Brasileiros).

19. O alto significado, a importância e as repercussões du "Concurso Teixeira de Freitas" são de tal ordem que dispensam maiores comentários. E uma providência que se justifica por si mesma, isto é, colocar o Municipalismo a serviço da cultura e da técnica para a prosperidade geral do País, através da investigação, pesquisa científica, rigorosa análise e formulação das melhores soluções para os problemas fundamentais dos Municipios dentre os quais avulta o imperativo de seu desenvolvimento planificado.

20. Por cutro lado, a realização dêsse empreendimento representa a máxima homenagem que se poderia prestar a $\mathrm{M}$. A. TeIXEIRA DE Freitas. Aliás, deixo de alongar-me sôbre a vida e a obra dêsse brasileiro insigne, na Justificação do Projeto de Lei incluso, porque julguei de bom aviso transcrever, como documentação anexa, dois documentos já incorporados ao patrimônio cultural e histórico do Municipalismo. Em primeiro lugar, coin o Docutnento anexo n. I, faço questão de reproduzir o depoimento do Sr. Deputado RocHa LouREs. O Discurso pronunciado pelo ilustre representante do Paraná a 31 de julho de 1956, reflete, com absoluta fidelidade, o pensamento de tôda a Nação e os sentimentos do Povo brasileiro a respeito da personalidade excepcional de M. A. Teixeira de Freitas. Em seguida, com o Documento anexo n. 2, cumpro o dever de transmitir à consideração do Congresso Nacional a Lei Pró-Municipio, na forma do texto original de TEIXEIRA DE Freitas. Também no que se refere à Lei Pró-Municipio, o Deputado Federal Antunes de Oliveira já se pronunciou em memorável discurso. Coube, efetivamente, ao eminente representante do Amazonas fazer um estudo amplo e profundo da obra de Teixeira de Freitas. O Deputado Antunes de Oliveira prestou, de resto, um serviço de extraordinária importância à Naçäo brasileira : com rara capacidade e patriotismo, o conhecido parlamentar amazo nense resumiu, atualizou e transformou em Projeto de Lei idéias e concepções básicas de TeixeIRA DE Freitas. Dai o Projeto de Lei n. 3.112-57 que estabelece as diretrizes e bases do Plano Nacional de Obras, Empreendimentos e Servişos Municipais. No desempenho de missão qute the foi confiada pela Associação Brasileira de Municipios e, atendendo a uma Recomendação Esperial do IV Congresso Nacional de Municípios, o Deputado Antunes de Oliveira tornou possivel o aproveitamento da Lei Pró-Município e demonstrou com o Projeto n. $3 \cdot 112-57$ a sua plena exeqüibilidade.

21. Finalmente, o "Concurso Teixeira de Freitas", na forma do Projeto de Lei que tenho a satisfação de encaminhar à apreciação dos eminentes 
Representantes do povo brasileiro, já mereceu integral aprovação dos prefeitos, vereadores, técnicos e autoridades que participaram do IV Congresso Nacional de Municípios reunido, nesta Capital, em maio de 1957.

Êle traduz, portanto, uma legitima aspiração nacional. - Souto MAIor.

\section{III - DOCUMENTAÇス̃ ANEXA}

TEIXEIRA DE FREITAS E A OPERAÇÃO MUNICÍPIO

Doc. n. 1

Deputado Federal Rocha Loures, Presidente da Comissão de Segurança Nacional (Câmara dos Deñutados).

REQUERIMFNTU

Senhor Presidente :

Requeiro a V. Ex $x^{a}$, saja dada a palavra em Explicação Pessoal ao Deputado RocHA Loures.

Sala das Sessões, em 31 de julho de 1956. - as. Armando Rolemberg.

O Sr. Presidente :

Tem a palavra o Sr. Rocha Loure.

O Sr. Rocha Loures:

(Em explicação pessoal, lê o seguinte discurso).

Sr. Presidente, o País recebeu, profundamente consternado, a notícia do desaparecimento do eminente brasileiro M. A. Teixeira de Freitas.

Nenhum brasileiro culto ignora, certamente, a significação dessa perda .

Ainda em pleno vigor, quando mais uteis e preciosas se revelavam ds energias $€$ esforços dessa extraordinária personalidade, desapareceu a figura exponencial de T'erxeIra dE Freitas, o legitimo criador do nosso sistema geográfico, estatístico e censitário, inseparável companheiro do sábio e nâo menos ilustre cientista patrício, Prof. Carneiro Felipe, de saudosa memória

"Servidor :público n. 1 do Brasil" - era assim que o Presidente Getúlıo VARGAS costumava se referir a fascinante personalidade de TEIXEIRA DE FREITAS. Trabalhador infatigável, senhor de prodigiosa e multiforme cultura M. A. Teixeira de Freitas morreu vitima de excesso de trabalho, responsabilidades e encargos de tôda ordem, a serviço do Brasil e de seu Povo. Morreu pobre porque jamais cuidou de sua pessoa e dos seus interêsses privados - que tôdas as suas horas e todos os seus pensamentos convergiam para os problemas e aspiraçóes fundamentais da nacionalidade.

Não desejo, Senhor Presidente, fazer um estudo neste momento sôbre a vida e a obra de TeIXEIRA DE Freitas: essa é uma tarefa para os seus biógrafos e para os estudiosos das realidades brasileiras. Apraz-me, no entanto, lembrar uma de suas principais contribuições, o conhecido ensaio sôbre "Os Problemas de Base do Brasil" que resumem, com admirável precisão e clareza, o ideário e a luta sem paralelo de uma existência inteira consagrada ao fortalecimento, expansão e prosperidade do nosso País. 
Os "Problemas de Base do Brasil" - verdadeira Biblia e roteiro das novas gerações brasileiras de estatísticos, economistas, técnicos de administração, oficiais superiores das Fôrças Armadas, educadores, intelectuais progressistas, políticos de bom aviso - em resumo os homens de cultura e responsabilidade dêste País - constituíram o supremo objetivo da vida fecunda e exemplar de TeIXeIra DE Freitas. Qual o verdadeiro homem de pensamento e de ação em nossa Pátria que desconhece o exaustivo e benemérito apostolado civico de TEIXEIRA DE FREITAS, sempre vigilante e dedicado ao estudo das magnas questões da nacionalidade na estafante busca de soluções exatas e adequadas aos verdadeiros interêsses e aspirações da nossa Terra e do nosso Pevo?

M. A. Teixeira de Freitas dispensa quaisquer elogios póstumos, êle que em vida já estava sendo consagrado pelos seus contemporâneos como autêntico sábio, da nobre e rara estirpe dos homens impolutos dominados pela paixãı de bem servir.

Não tenho conhecimento, Senhor Presidente, de outro movimento entre nós, semelhante ao que levou o Govêrno da República, há alguns anos, a inscrever o nomz de TeIXeIRA de Freitas Livro do Mérito: foi um pronunciamento unânime e consagrador das nossas elites aquela singular e alta personalidade de estudioso, de homem de bem e de admirável envergadura moral, técnica e humana.

Mas, Senhor Presidente, a maior homenagem que se poderia prestar ao egrégio criador do I.B.G.E. e de tantas contribuiçōes essenciais ao desenvolvimento do Brasil, faço questão de apresentá-la, em nome do meu Estado e das novas gerações brasileiras que vêem no Mestre desaparecido, acima da tudo, um modêlo e um exemplo inimitáveis de capacidade profissional e integridade moral. Assim em nome ainda da Associação Brasileira de Municípios, cabe-me a honra de transmitir ao conhecimento da Nação e para que fique constando dos Anais do Congresso Nacional a última contribuição de M. A. Teixeira de Freitas ao progresso do Brasil e bem-estar do seu Povo Cumprindo uma deliberação do Conselho Deliberativo da Associaf̧ão Brasileira de Municípios em sua última reunião, levada a efeito na Câmara de Vereadores do Rio de Janeiro, submeto com justificada emoção e justo orgulho ao exame do Parlamento Brasileiro, o extraordinário Projeto de Lei do grande Patrício - a monumental "Lei Pró-Municipio" cuja elaboração $\epsilon$ aprimoramento consumiram os seus últimos meses de vida. Trata-se, Senhor Presidente de um projeto de Lei transcendental no qual M. A. TEIXEIRA DE FREITAS trabalhou com entusiasmo e inexcedivel dedicação. Pretendia o grande brasileiro desaparecido que o seu Projeto fôsse apresentado como Substitutivo à Operação Municipio - magno agregado de empreendimentos, obras e serviços destinados a promoverem a definitiva emancipação $e$ desenvolvimento planificado das Comunas brasileiras. Dificilmente se encontrará nos Anais do Parlamento Brasileiro, Senhor Presidente, documento semelhante ao que tenho a honra de submeter à apreciação dos Senhores Representantes do Povo brasileiro nesta Casa do Congresso Nacional: a "Lei Pró-Municipio" condensa tôdas as experiências da vida profícua e digna de TeIXEIRA DE Freitas; ela representa uma dessas construções ciclópicas e basilares na vida de um Povo e ficará como imperecivel monu- 
mento, direi melhor, uma poderosa "idéia-fôrça" a impulsionar o Brasil para os cam nhos da prosperidade.

O Substitutivo ao Projeto de Lei n. 4.614-54 do então Deputado Jarbas Maranhão, que ora solicito a Vossa Excelência se digne encaminhar ao exame aprofundado das Comissões Técnicas do Congresso Nacional, constitui, na realidade um legítimo Código das aspirações dos Municípios brasileiros, um Roteiro para superação das crises que nos afligem. Ponto de partida e conjunto orgânico de providências que deverão encerrar, de uma vez por tôdas, o ciclo das improvisações e do subdesenvolvimento.

Nos últimos meses de sua existência trabalhava TeIXEIRA dE Freitas em estreita articulação com a Associação Brasileira de Municipios no sentido de aperfeiçoamento e apresentação da "Lei Pró-Municipio". Infelizmente a obra ciciópica de que nos dá conta o Projeto da "Lei Pró-Município" não pêde ser burilada e aperfeiçoada como o desejava o insigne Mestre desaparecido: faltou-lhe tempo para fazê-lo; 0 destino năc o permitiu. Não obstante constituir apenas um esbôço do que pretendia apresentar - uma hipótese de trabalho e ponto de partida para a obra definitiva - a "Lei Pró-Municípic" é de tamanha envergadura que a Associação Brasileira de Municipios por proposta dos seus Conselhos Deliberativo, Diretor e Fiscal, recentemente reunidos, deliberou sob aclamações encaminhá-la assim mesmo, apenas delineada ao Conselho Nacional ao mesmo tempo em que somo singela homenagem ao inesquecivel Patrício, inaugurava em sua sede própria a Sala Teixeira de Freitas.

Nestas condições, tenho a honra de requerer a Vossa Excelência, Senhor Presidente, se digne encaminhar à meditação, estudo e debate do Congresso Nacional, e anexo "Substitutivo ao Projeto de Lei n. 4.614-54 do então Deputado Jarbas MarAnHÃo, cuja publicação espero seja feita oportunamente onde se estabelecem as Bases e Diretrizes para o Plano Nacional de Obras, Empreendimentos e Serviços (Operação Município).

Era o que tinha a dizer. (Muito bem; mutito bem) $\left({ }^{*}\right)$ Deputado Federal Rocha Loures.

\section{“LEI PRÓ.-MUNICÍPIO}

Substitutivo ao Projeto de Lei $n^{\circ} 4.614-54$ do Deputado Jarbas Maranhão, onde se estabelecem a.j bases 6 airetrizes para o Plano Nacional de Obras e Serviços Municipais (Operação Municipio).

\section{SLIMÁRIO}

- Breve Justificação

- Capitulo I - Disposiçỉes Preliminares (arts. 1\% a 7ః)

- Capitulo II - Da "Cperação Município" (arts. 8 a 25)

- Capitulo III - Da Cuoperação Intermunicipal (arts. 26 a 34)

- Capitulo IV - De: Circunscricionamento Municipal (arts. 35 a 37)

- Capítulo V - Dos levantamentos Geográficos, Cadastrais e Estatístico Censitários Municipais (arts. 38 a 63).

(*) Transcrito do Diário do Congliesso Nacional de $1^{\circ}$ de agôsto de 1956 (Seção I) - pp. 6.123/6.124. 


\section{BREVE JUSTIFICAÇÃO DO SUBSTITUTIVO AO PROJETO DA OPERAÇÃO MUNICIPIO}

E' irrecusável que o projeto de lei referente à "Operação Município" se reveste de transcendente alcance social, econômico e politico. Destinou-o o seu ilustre autor, o Deputadc JaRISAS MARANHão, a atender ao clamor mais instante, na presente hora, da Nação Brasileira.

O anseio nacional a que o projeto da "Operação Municipio" corresponde, foi firmementz expresso pelo voto do Congresso de Municípios, realizado em São Lourenço, entre 16 e 22 de maio de 1954 , no sentido de que a União Federal, abandonando as contemporizações e as meias medidas, enfrente de ânimo resoluto a crise tremenda que a assoberba. Isto é, lance mão, para tanto, do único mas eficaz recurso que lhe está realmente ao alcance. E qual é êsse recurso? Conquistar laboriosamente a riqueza, evitando os malabarismos financeiros. Estabelecer, com inteligência e firmeza, uma sadia orden social e econômica, na ausência da qual o país não podz viver nem trabalhar tranquiilamente. Assegurar o equilibrio politico entre os diferentes planos da vida nacional, apelando para o aproveitamento racional dos recursos do seu solo, a proteção eficaz ao trabalho do seu povo, a integração do seu quadro de civilização. Mas dirigido tal esfôrço antes de mais nada, à infra-estrutura da "organização e da "vida municipal" de maneira eqüitativa, harmoniosa e que dê cobertura à totalidade do pais.

Enquanto não forem realizados tais objetivos, a Nação corre, perigo, caminhando tatalmente para uma desordem crescente, cujo desfecho só pode ser a revolução. Revoluçào sangrenta e perigosa. De rumos incertos. E de resultados ainda mais incertos, quanto à sobrevivência da unidade nacional, que é, entretanto, a garantia da grandeza histórica do Brasil. Mas se o Brasil teimar em inanter o triste "slogan" do "deixar ficar como está para ver como é que fica", nâo podemos esperar senão uma vida inglória e infeliz. Para cada cidadão, para cada comunidade e para tôda a Nação. E não se vê-como possa a República transcender a um nivel de civilização em que venham a desaparacer os fatôres negtivos que imprimem à atualidade brasileira a configuração absurda da "miséria na opulência", como o quadro social mais estranho entre us que ora se exibem à face do mundo.

Não é difícil fixar - porque todos o vêem e o sentem - em que sentido a nossa Federação terá de caminhar se quiser manter-se como uma das mais belas promessas da civilização americana. Mas, se não há dificuldade no traçar o esquema orgânico que é essencial ao esfôrço de recuperação nacional, para garantir o progresso sem perturbar. a ordem, - logo, rigorosamente dentro dos quadros legais - já será um processo técnico-financeiro e econômico-social bastante difícil, o lançar-se a emprêsa da recuperação nacional consoante um mínimo de sacrilícios para todos, e com a amplitude, a gene. ralidade, o espirito de sistema, que se tornam mister.

Trata-se, com efeito, de uma resoluta iniciativa de salvação nacional. Sem dúvida, o empreendimento não é de menor alcance do que a arrancada histórica das "entradas e bandeiras". que modelou e integrou o Brasil. A bem dizer, a nova cruzada tem que repetir ou renovar o lance épico da conquista. Porém, segundo motivos e esquemas atualizados e conforme- 
mente a "planos" bem estabelecidos que mereçam tõda a confiança. "Assim é preciso para que, em vez da salvacão esperada, não resulte o empreendimento em debacle financeira, administrativa $\in$ política, a envolver tôda a vida nacional, agravando a situaçăo brasileira e apressando o que se quer evitar - o caos econômico e social, que nos ameaça e se aproxima inexoràvelmente, de dia para dia.

Dificuldade, contudo, não quer dizer impossibilidade. Se dificuldade há, e é inegável, aí só se veja o incentivo ao estồrço mais enérgico, bem ordenado e prudente. Esfôrço que não se interrompa em forma duplamente desastrosa - quanto aos fins e quanto aos meios. Enfrentando-se o problema em tôda a sua ruagnitude, a solução será encontrada forçosamente.

Năo há problema de "arte politica" a que a inteligente, corajosa e oportuna "ação politica" não poşa dar solução pacitica e plenamente satisfatória. Seria êrro imperdoável stipor-se que a solução justa houvesse de fugir aos quadros lógicos. Ou huuvesse de expor a riscos imprevisiveis e perigos insuportáveis as estruturas sociais e econômicas do país. Êrro seria, igualmente, aceitar-se o postulado de que as grandes mudanças históricas. desencadeadas por motivos de justiça, ou para reaiizar nobres anseios do povo por uma ordem melhor, e que não tôssem, portanto, meras contingências fortuitas, imjostas por eventos imprevistos tal como uma guerra aceita mas não desejada, só pudessem resultar de sacrifícios tais que a Nação, não premida por vontade estranha, nem submetida a um estado de necessidade, não pudesse enfrentar de boa mente. E tanto menos se repeliria tal eventualidade, quanto é certo que a tibieza de vontade, o temor de todo esfôrço ou sacrifício, êste simn, nào acarretaria outra coisa, e a bem breve prazo, senão sacrifícios imprevisiveis. Tais sacrificios com que a inércia nos ameaça, êstes é que se tornariam insuportáveis. $€$ êles serão cada vez maiores, ninguém pode dizer até que ponto, se nào tivermos quanto antes à coragem das soluções viris .

O que se faz preciso, entretanto, para a solução acertada que todos desejamos, e ainda nos está à vista felizmente, é bem pouco. Bastará que as fôrças políticas compreendam, como não podem aeixar de compreender, quanto já é sombrio e ameaçador o quadro da atualidade brasileira. Essa clara compreensâo da realidade thes sugerirá forçosamente a ousadia das atitudes necessárias, e com essa decisão, os motivos para esquecer as divergências que, apesar de tudo, ou por isso mesmo, esta hora tão grave acasó lhes pudesse oferecer. E dai resultará, pôsto a operar o movimento de união nacional, acima dos divisores partidários, sob a excutisiva inspiração do beri maior para o Brasil, que os representantes da Nação cheguem a adotar com plena confiança un "Plano de Base" para a reconstrução brasileira. Basta, por conseguinte, qua tal plano se inspire e se ordene, meticulosamente, na conformidade do que sugere a todos os espiritos a própria situação geral do país.

Insta igualmente que a êsse plano queira e consiga o Poder Legislativo imprimir o "sentido integral" que êle precisa ter, a bem da unidade brasileira e da justiça e bem-estar para todos os brasileiros. Isso não implicará senão que se peça aos grupos sociais já favorecidos com as comodidades da civi- 
lização, que consintam em pequeno sacrifício pecuniário. Um quase nada. Algo que não virá empobrecer realmente a quem quer que o sofra. Sacrifício, ademais, que se fará largamente compensar merce das próprias realizações que a Nação precisa empreender, mas que só poderá empreender se a insignificante contribuição pedida aos donos da riqueza fôr bem aceita, lealmente oferecida e aplicada em todo o interior do país de maneira reprodutiva, justa e adequada às necssidades da República.

O projeto da "Operação Municipio" contém, não há dúvida, na prudente forma original sob que foi lançado, tudo de que o Brasil precisa no presente momento. Mas, estando cada coisa disposta, no primitivo esquema que the foi traçado, conforme mecanismo por demais singelo, excessivamente lento será o desenvolvimento do plano. Mesmo seu êxito final ficará talvez comprometido, ou pelo menos em suspenso, porque dependerá de intercorrentes mudanças de orientação, capazes de prejudicar ou deter as providências postas em marcha. A continuidade é, sem dúvida, a condição "sine qua non" para empreendinentos de amplas dimensoes como o de que se trata. E essa continuidade exig\%, não um apenas, mas sucessivos planos qüinquienais. Planos, senão progressivamente mais vigorosos e extensos, pelo menos em condições de não retrogradaram ou esmorecerem a tal ponto que venha a ficar, em qualquer fase do seu desenvolvimento, abaixo do mínimo exigido para o aproveitamento a pleno efeito do esforç̧o construtivo que se se conseguir desencadear.

Isto sugere oportunas e bem assentadas inclusões no "Plano da Operação Municipio". Tudo indica a conveniência, sanão a necessidade, de que abranja êle certas "medidas de base". São, essas medidas, aquelas sem as quais nem a estrutura municipal do país se integrará, revitalizará e consolidará, como é preciso e urgente, nem tampouco se lhe deixará ao alcance a capacidade civilizadora que a essa mesma estrutura é essencial e somente um plano de conjunto ben: concebido e aplicado pode assegurar satisfatòriamente.

Por outro lado, é preciso fixar, desde logo, os recursos financeiros, tanto para o lançamento, como para a continuiação da "Operação Municipio". Sem essa prévia e segura garantia, tudo que se tentar não passará de um esfôrço frustro, mera aparência de construção a modelar nada mais que areia umedecida.

Mas ocorre ainda um terceiro e não menos importante aspecto. Faz-se mister, também, que se tracem nitidamente e d'antemão as linhas mestras do esfôrço reconstrutivo para o qual os Municipios brasileíros, todos êles sem exceção, devem ser imediatamente corriocados e predispostos. Mas não sem que se tomem as medidas necessárias para evitar quanto possivel, não só os "erros de origem", como, também, os "desvios de orientação", que prejudiquem o normal desenvolvimento do plano ou lhe retirem a fôrça realizadora; ou, ainda, o impeçam de atuar uniformemente, como se faz indispensável, eim tôda a extensão do território racional.

Dai o stubstitutivi cujo encaminhamento se pretende.

Com os desenvolvimentos propostos, a "Operação Municipio" articula-se tal como parece essencial com as três outras "Oparações" conexas, 
que efetivamente lhe condicionam o êxito, como o verificară quem quer que se detenha a refletir sôbre a matéria com algum conhecimento da realidade brasileira.

É, em primeiro lugar, o sistema prático da cooperação entre os próprios Municipios. Sòmente êsse sistema assegurará à organização municipal a sua efetiva autonomia, com a garantia da "permanência" e "integridade" para a seu potencial demográfico. econômico e financerro. Sòmente por meio dêsse sistema, também, sé conseguira para os Municipios - para todos êles sem exceção alguma - o aparelhamento técnico cuja ausência até hoje não permitiu aos Governos Municipais disporem amplamente das vantagens de uma administração racionalizada, bem aparelhada e bem provida de pessoal especializado. Essse "plano" suplamentar instituirá, igualmente, a rêde de prósperas e bem organizadas metrópoles interiores, servidas de fáceis comunicações e de todos os recursos da civilização, sem cuja presença próxima não teriam ponto de apoio suficiente os esforços pioneiros que se fazem mister, em tôda a parte, em prol do desenvolvimento agrário em larga escala, e sob métodos modernos, na seneralidade dos Municípios, mas principalmente em relação a grande parte ainda inexplorada - e que é a maior - do território nacional.

São de caráter complementar os dois outros planos a articular com o da "Operação Municípic".

O primeiro dêles é o do racional desenvolvimento e integração satisfatória do "quadro municipal". E" um objetivo que não poderá ser conseguido desde que não se resguardem os "interêsses nacionais" que o assunto envolve. Há-de continuar a exercer-se livremente a autonomia estadual, sem dúvida; mas insta estabelecer e fazer funcionar harmônicamente o escudo de que carece a autonomia municipal. Porçue tanto merece ser protegida essa «autonomia» quanto a «autodeterminação» que, na matéria, cabe igualmente à Uniăo e ao Esstado.

Essa, e não outra, a maneira prática para que também se evite a dupla impotência que até hoje prejudicou ou frenou a atuação dos Municípios. Isto é, como resultado de possuir c Município, - em vez de um bem proporcionado espaço geográfico, come seu junto "lugar ao sol" - ou um território "pequeno demais", ou, ao invés, um território "demasiado extenso". O plano sugerido, por isso que focaliza e resolve hàbilmente a questão, pôde prover ao mesmo tempo a que, pela ação conjunta da União, do Estado e do Município, cada qual na medida de suas possibilidades, venha o território nacional a ser devassado na sua totalidade, e efetivamente ocupado em pequeno prazo, recebendo a colonizaçãc intensiva, bem dirigida, e qualificada - nacional o:1 estrangeira, - de que carece o pais em quase tôda sua extensão territorial.

Vem em últino lugar, como condicionamento e complemento, por igual indispensável ao êxito da "Operação Municipio", o plano que assegure a integração - e com esta o aprofundaniento e a intensificaçäo dos esforços - do Instituto Brasileiro de Geografia e Estatística. O Instituto é, entre os muitos sistemas interadministrativos que a "Operação Municipio" vai mobilizar, aquêle que se apresenta como o mais essencial à revitalização municipal 
do Brasil. Isto não só porque foi a essa instituição que coubz suscitar e amparar a própria campanha rinnicipalista. Mas, também, porque por meio dela é que sc experimentou, em âmbito nacional, a idéia cooperacionista, que é o próprio fundamento da "Op̣eração Municipio". Além disso, fôrça é reconhecer-se outro fato. Foi graças à atuação do Instituto, dia a dia ampliada e aprofundada, que ficou colocado em têrmos positivos o problema do Município, no Brasil, em função das duas outras estruturas nacionais - a estadual e a federal. O Instituto, não obstante suas deficiências, que ainda são grandes, já fêz sentir, e está demonstranco cada vez mais claramente, tudo quarito, de caráter essencial, ainda precisamos, em matéria de conhecimento estatístico e geográfico, para que a recuperação da vida municipal se possa processar a pleno efeito.

O que o substitutivo dispõe, a êsse respeito, satisfaz cabalmente. E' a experiência quem no lí assegura. O esquema proposto corresponde não só aos objetivos municipalistas do I.B.G.E. mas também ao próprio papel que também the cumpre desempenhar em face da União e dos Estados. Completando o sistema, e assegurando-lhe os recursos financeiros na medida justa em que forem crescendo stias responsabilidades, diante da expansão da massa demográfica, raultiplicação das circunscrições e diferenciação dos aspectos econômicos, sociais e culturais da vida nacional, o plano áqui considerado provê, entretanto, ao seu financiamento sem aumento de despesa. Apenas simplifica e racionaliza a estrutura do sistema. E com isto garante-lhe a eficiência integral. Tal não se poderia esperar, apenas, da "coordenação técnica" dos serviços, já em grande parte conseguida. Depende basilarmente da "coordenação adninistrativa". E o projeto visa a estabelecer essa coordenação sob a mais equilibrada das formas. Sem uma só desvantagem para qualquer das órbitas de Govêrno, mas com vantagens numerosas e muito grandes para cada uma delas.

Segundo o projeto, as peças do sistema que ao Instituto de Estatística servem de "órgãos centrais" - - Departamentes Estaduais e Serviçrs Ministeriais - passam a desempenhar de fato êsse papel. Mas, já agora, com tôdas as condições necessárias para que o Instituto lhes possa dar a eficiência requerida e assim servir melhor tanto aos fins da União como aos fins dos Estados e Municipios. Os recursos financeiros especiais para tanto são pedidos, não as atuais receitas federais, estaduais ou municipais; devem provir, sim, como é natural, de uma fonte tributária que as sup'srte tolgadamente. Mas a módica contribuição especial, que é pedida, năo chega a ser sacrifício apreciável aos seus consignantes. Além do que tenderá a liberar, em benefício dos Tesouros de cada uma das órbitas do Govêrno, as verbas que atendem às despesas attiais da Uniăo, dos Estados e dos Municipios, quase em correspondència rigorosa ao q̨uantitativo global que se procura reservar ao instituto. São cêrca de 450 milhổes de cruzeiros anualmenté. Tal importância vai ficar disponivel, tanto para os Municipios, co:as para os Estados e a União, à 1azão de i'so milhões de cruzeiros para cada uma das três órbitas administrativas. Isto quer dizer que o plano apela para um sacrifício mínimo - e proporcional às respectivas possibilidades - a ser suportado pela categoria de contribuintes para tanto mais qualificada. E 
êste minimo sacrifício permitirá que c. Sistema Estatístico Brasileiro, hoje mundialmente conhecido - - 2 reconhecido nos meios técnicos como de original e feliz concepção, - passe a realizaı em condições muito melhores, tanto em extensão quanto em profundidade, e sobretudo em qualidade, a estatistica brasileira, uma das mais difíceis do mundo. Não se sobrecarregarão os orçamentos atuais da "despesa pública", e ficarão favorecidos os respectivos orçamentos da "receita" com a inportância total que o poder público ora dedica à Estatística. A mais disšo, êsses mesmos recursos propiciarão uma nova rêde prospectiva e informativa, bem maior e mais eficiente que as demais já experimentadas. E' a que atuará, agora, no plano da 'organizaçäo distrital". A par disso, o esquema proposto assegura, ainda, uma rêde de "rádiocomunicações" e outra de "transporte aéreo", entre todos os Municípios do Brasil. Essas duas rêdes terão papel marcante nas próprias atividades do Instituto; mas tambént servirão suplementarmente, e de um modo geral, a todos es Governos em caso de emergència, servindo igualmente, e sobretudo, aos interêsses da segurarç̧a nacionaı.

E' fácil verificar, ademais do exposto, que o substitutivo vai restituir aos Municipios, mas já entãu com os recursos necessários para movimentálos, não poucos campos ou setores áministrativos que, erradamente, vinham sendo explorados sem sua participaçãc, quer pela União quer pelos Estados, quando deveriam sê-lo, ou exclusivamente, ou predominantemente, pelas Administrações Municipais. O plano traçado parmite igualmente a efetiva e racional descentralização, com apoio na rêde de metrópoles dos Consórcios, de numerosos serviços federais e estaduais, mas que, sem embargo de serem geralmente muito onerosos, permanecen $n_{\iota}$ quase inoperantes, em virtude da centralização que lhas detèm a exfarsăo e os paralisa. Descentralizados racionalmente, mercê da nova estrutura municipalista que a Lei Pró-Municipio esquematizará, então a localização de tais serviços no interior do pais se imporá, sem mais os embataços quie ora a impedem, ficando aos mesmos serviços também assegurada a ajuda eficaz, que em verdde não pode sei dispensada, dos próprios Municípios.

O esquema esboçado encaminha ainda:

a) o levantamento do cadastro territorial e a efetividade do Registrc Civil nas zonas rurais, de maneira total;

b) a regular revisão dus mapas municipais em seguida às novas divisões territórios e o levantamento das plantas cadastrais, com os respectivos planos urbanisticos, das cidades e vilas de todo o país;

c) a recuperação dos elementos marginais da nossa população (Colônias-Escola e Comandos Militarizados de Trabalho);

d) a ocupação, de fato, a colonização eficiente, do território nacional com a criação de tantos novos centros judiciário-administrativos (Distritos Municipios, Têrmos e Comarcas) quantos necessários para que, atuando cada qual segundo sua categoria e em espaços geográficos compativeis com a missão assistencial e civilizadora que lhe caiba desempenhar, fique em verdade todo o ecúmeno brasileiro sob a ação da soberania nacional no seu duplo 'aspecto de "jurisdição" e "proł́eção"; 
c) a formação de uma dêde de cêrca de trezentas excelentes cidades interiores;

f) a interiorização até o Município, ou mesmo até o Distrito, das fôrças de progressı que ainda não puderam até hoje penetrar no Brasil;

g) a expansão planificada do enorme potencial econômico e social que já oferece ou poderia oferecer o Brasil em tôdas as regiões e rincões do seu amplissimo território, e que, entretanto, permanece inaproveitado em virtude de não serern postas em cbra elementares medidas de organização e estímulo, as quais só teriam de difícil o conseguir-se, como medida liminar, seu bem ordenado "encadeamento" e sua "continuidade", tal como exatamente predispõe o projeto;

h) a efetiva organização, en benefício de tôda a população brasileira, sob a égide da estrutura e organização municipal, dos serviços de saúde pública, de higiene, de educação e cultura popular, e de fomento rural, de que até $\mathrm{c}$ presente estêve o Brasil absurdamente privado;

i) a possibilidade de largas iniciativas tanto públicas como privadas, distribuídas simultâneamente por tôdas as circunscrições municipais e que cubram, na realidade, todo o território pátrio; para que assim se valorize a vida nacional, e se retiremn do espaço geográfico, até agora desocupado e abandonado, os recursos económicus e tinanceiros que permitam ao Brasil superar definitivamente a crise que o esmaga e garantir ao seu povo, no futuro, não apenas um razoável nivel de bem-estar e confôrto, mas realmente um ambiente renovado, no seio do qual a Nação respire melhor e póssa realizar bem à vontade a impetuosa obra de civilização e cultura que lhe é necessária e está, sem dúvida, an alcance do seu espírito de empreendimento e capacidade de organizar-se inteligentemente.

Esta, em linhas apenas muito gerais, a justificativa do projeto. Seu transcendente alcance, entretanto, quer na ordem social e econômica, como também no aspecto politico, envolvendo as garantias de segurança nacional e de sobrevivência da Féderação, transparece em cada um e no conjunto dos dispositivos alvitrados. Possa, pois, o substitutivo merecer a compreensão e o beneplácito do Poder Legislativo. Se conquistar a sua confiança e levá-lo a propiciar ao país, ccin a "Operação Municipio", a extensa obra renovadora que a Naçãn inteira impetra em altas vozes e num estado de consciência coletiva como raramente temos visto entre nós, esta será a primeira emprêsa em grande estilo, a aue nos teremos animado, em prol da reconstrução brasileira. Ela vai operar a partir dos alicerces, a bem dizer, nas infra-estruturas da Federação. Mas assumirá alcance "nacional", no mais elevado sentido da expressão, melhorando a viaa brasileira em todos os aspectos. Quanto mais a fundo se 1ueditar sôbre êste plano quádruplo mais peremptòriamente sé verificará que venhum ourro esquema pode ser alvitrado em condições de assegurar ao esfôrço de construção do Brasil impulso mais fundamental, mais extenso, em rnaior profundidace e com a intensidade tão bem proporcionada às reais necessidades das variadíssimas regiões brasileiras. - M. A. TeIXeira de Freitas. 
SUBSTITUTIVO AO PROJETO DE LEI N $N^{4}$ 4.614-54 DO DEPUTADO JARBAS MARANHÃO, ONDE SE ESTABELECEIVI AS BASES E DIRETRIZES PARA O PLANO NACIONAL DE OBRAS E SERVIÇOS MUUNICIPAIS (OPERAÇÃO MUINICIPIO).

\section{LEI PRÓ-MUNICÍPIO}

\section{CAPITULO I}

\section{Disposições Preliminares}

Art. 12. Fica instituído, nos têrmos desta Lei, o plano nacional de diretrizes e bases, e, concorrentemente, de iniciatıvas, acôrdos e procedimentos intergovernamentais, por forç̧a do qual se assegure a aplicação, a pleno efeito, dos principios do regime republicano-federativo fixados na Constituição, no que respeita ao reerguimento sócio-econômico e político-administrativo dos Municípios.

Parágrafo únicu. Complementarmente, a presente Lei desenvolverá a aplicação dos mesmos principios do regime politico aos aspectos básicos correlatos;

a) da cooperação intermunicipal;

b) do circunscriciolamento territorial primárı, de ordem judiciárioadministrativa;

c) dos levantamentos to território e demais aspectos geográfico-estatísticos das condições de cunvivência social das comunidades municipais e de cada um dos respectivos Distritos.

Art. 29 Esta Lei corporificará, de forma geral, imperativos e condicionamentos - geográficos, sociais e politicos - que devem regular, no que toca à matéria considerada, o solidário comportamento, no domínio prático, das três órbitas autônomas da administração pública nacional.

Parágrafo único. Aplicar-se-á para êsse fim a cooperação intergovernamental, como princípio basilar da organização politica brasileira. Nessa aplicação, as autonomias governamentais ou autarquias administrativas, emergentes do regime constitucional, e postas paritàriamente em presença umas das outras, se articularão entre si, mediante fórmulas convencionais adequadas, de caráter orgânico, na consecução dos fins comuns, sempre que interfiram simultâneamente, por motivo de coexistirem - independentes e eqüidistantes entre si, mas concorrentes - as respectivas competências.

Art. 3. Sob o aspecto formal ou expositivo, o disposto na presente Lei, que é, ao mesmo tempo, plano e programa e ainda ato e manifesto convocatório, estabelecerá, para assim bem atender ao seu tríplice objetivo:

a) obrigaçóes e autorizações de caráter federal e campo nacional;

b) princípios e diretrizes, bases e padrões, esquemas e normas gerais, tendo por alvo que os interêsses da União se realizem, sempre que possivel, mediante apenas a simples coordenação nacional prèviamente definida dos fins visados pelos Estados e Municípios; ou, então, que a ação federal, até onde e como convém, se vincule ou associe pràticamente à ação estadual e 
municipal, conforme planos preestabelecidos, naqueles campos de competência ou interêsse comun, ligados ao objetivo geral firmado no artigo 1 .

Art. 4: Como apoio aos esquemas que a Lei se limita o oferecer no propósito de orientar a ação comtim - mas sempre autônoma em relação a cada órbita de govêrno - dos Estados e Municípios, o contexto normativo invocará, nada obstante, no desenvolvimento dos esquemas e modelos preferidos:

a) os textos constitucionais que orientaram as diretrizes, bases, condicionamentos, esquemas e preceitos assentados;

b) os fundamentos lógicos, políticos ou práticos para a unidade de ação que deva ser adotada pelos Governos a que interessar o seu cumprimento "in solidum", tendo e.m mira, liäo só as respectivas prerrogativas de autonomia, mas, também, a intenção de que a plena solidariedade a estabelecer entre as diferentes órbitas governativas assuma sentido construtivo de àmbito ou compreensão nacional:

c) os acôrdos governamentais já firmados ou por firmar para que, na conformidade das respectivas disposições constitucionais; possam ser completamente atingidos os fins vacionais do plano previsto.

Art. 5० A execuçäo do plano geral a que se refere a presente Lei terá por fim desenvolver, em condições eqüitativas e eqüânimes - a par do efetivo rearguimento - a potencialidade $e$ as intrinsecas virtualidades. da vida comunal da Federação.

Parágrafo único. O objetivo proposto neste artigo será realizado por meio da conjugação harmônica e livre convergência, em forma cooperativa, e mercê tảmbém do seu máximo desenvolvimento, das atividades administrativas que, diversificando-se no plano politico onde se originam e são reguladas, aos mesmos campos se dirigem, ou devem vir a dirigir-se de maneira concorrente, no intuitc: de transformar, prontamente e de fato, todos os Municipios em outras tantas unidades eficazmente operantes "in solidum", na realização da ordeın e do progresso nacional.

Art. 6? O "plano geral" traçadc na presente Lei compreenderá os quatro seguintes "planos especiais":

a) o da "Operação Município" (plano de obras, empreendimentos e serviços municipais de naturezá mais urgente provendo também ao financiamento da revitalização);

b) o da «Cooperação Intermunicipal» (instituição autárquica dos Consórcios Municipais), firmada na solidariedade convencional, para os fins da "Operação Municipio" das Municipalidades entre si, e entre estas, assim associadas, de un lado, e c Estado e a União, de outro, mas também intervinculadamente entre si, visando ao fortalecimento sócio-econômico e administrativo, em comum, das Unidades componentes de cada Consórcio;

c) o do "Circunscricionamento Normalizado do Quadro Municipal" (condicionamentos básicos para a criaçáo de novos Municípios e provimento à subdivisão adequada, ocupação $c$ desenvolvimento econômico e social das áreas desabitadas, escassamente povoadas, ou ainda sem organização agrária): 
d) o dos "Levantamentos Grográficos, Cadastrais e Estatístico-Censitários dos Municipios» (cartografia, medida e devassamento dos territórios municipais, topografia cadastral das cidades e vilas, organização ou efetivação - a pleno efeito dos registros e cadastros rurais, além da prospecção sensitária e estatística geral; tudo executado, entretanto, a partir dos Distritos, com a objetivo de caracterizar a fundo, mas de maneira uniforme, harmônica e em uma única operação para todo o país, as condições geográficas e sociais de cada um dos Estados e da União Federal).

Art. 7: O objetivo primordial da cooperação intergovernamental a instituir será encaminhar, favorecer e garantir a obŗa de civilização e de integração nacional en tôda a República, a fim de que essa obra resulte como deve resultar, nas condições atuais do país, do comum esfôrço de todos os órgãos do Poder Público, uma vez consistentemente solidarizados entre si em prol da potencializaçào e soerguimento da vida municipal, compreendida esta na generalidade dos seus aspectos e de modo uniforme em tôdas as regiões, sub-regiões e rincões da Federação.

\section{CAPÍTULO II}

\section{Da "Operação Municipio"}

Art. $\delta$ : Como principal instrumento de ação para os fins que esta lei prevê e encaminha no que depende da União Federal, fica instituída e autorizada a "Operação Município".

Art. 99. A "Operaçãn Municipio" é o plano financeiro e de ação governamental no que tange a obras, empreendimentos e serviços, por parte da União, dos Estados e dos Municipios. Tem por fim assegurar o mútuo auxilio entre os Governos, de forma planificada e a consistente ajuda ao desenvolvimento solidárió e harmônico da vida comunal brasileira, compreendida esta na totalidade das Unidades territoriais já existentes ou que vierem a existir na Federação, como resultante do progressivo e sistemático desdobramento da divisão administrativa e judiciária dos Estados e Territórios.

Art. 10. Ponto de partida para a obra de expansão, de progresso e integração sócio-econômica e política da vida municipal da República, e como suporte técnico-financeiro para o esforç̧o de consolidar os alicerces sôbre que repousam as superestruturas da vida nacional, tem a "Operação Municipio" o objetivo innediato de instituir, desenvolver e apoiar "in totum", segundo um condicionamento político-administrativo de base, a solidariedade e a cooparação entre as unidades municipais enquanto elementos celulares do organismo nacional, isto $e$, integradas efetivamente em sua normalidade de organização e funcionamento, conforme o espirito e a letra da Constituição Federal.

Art. 11. A solidariedade previstá no artigo precedente é objetivo a ser atingido, como condição liminar, dentro de um sistema cooperativista que alcance tôda a Nação. Será estabelecida com apoio na Instituição conven- 
cional dos Consórcios Intermunicipais (Autarquias de Municipios Unidos, ou Uniões Municipais).

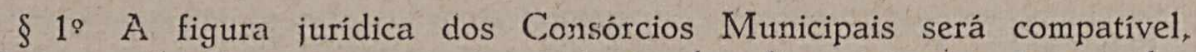
explícita ou implicitamente, com c conjunto das disposições constantes dos artigos $5^{\circ}, 31$, I e 156 da Constituição da República.

$\S 2^{\circ}$ Os Consórcios Munıcipais serão postos em ação sob a forma e nas condições que se estabeleceñ no Capitulo III desta Lei.

Art. 12. As "bases e diretrizes" previstas na presente lei, para o fim de organizar-se e implantar-se o Plano Nacional de Obras, Empreendimentos e Serviços ("Operação Município"), atém-se ao objetivo da Recomendação Especial aprovada no III Congresso Nacional de Municipios, realizado em São Lourenço, Minas Gerais, entre 15 e 22 de maio de 1954.

Parágrafo único. O plano de que trata o presente artigo abrangerá, no primeiro exercício, o respectivo ordenamento técnico-financeiro, a ins. talação dos Consórcios de Municípios, a um programa inicial de emergência. Seguir-se-á o «primeiro programa normal» a ser executado em cinco exercícios consecutivos, sob o regime da cooperação e convênio entre a União, de um lado, e, de outro, os Esfadios e: os Municipios que ao mesmo aderirem, obedecidos os princípios e precettos fundamentais consubstanciados nesta lei.

Art. 13. O Plano Nacional de Obras, Empreendimentos e Serviços Municipais ("Operaçào Municipio") terá como objetivo principal promover, de forma simultânea $\mathrm{c}$ em condições equivalentes, o desenvolvimento em conjunto dos Municípios brasileiros. De tal sorte que êstes se capacitem a pleno efeito ao seu destino constitucional como unidades sôbre as quais se apóie o progresso econômico-social do país, especialmente em seus aspectos agrícola-industriais, de preservação da saúde públıca, difusão do ensino técnico-profissional, aparelhamento para os transportes e comunicações e produção de energia.

$\S$ 1: O objetivo visado no artigo deverá sẹr alcançado mediante:

a) a criação - por Decreto Executivo que lhe fixará as instruções - da Comissão Nacional Organizadora do Plano;

b) a constituição da Caixa financeira especial, constituída de recursos vinculados às obras, serviços e demais empreendimentos que o plano vier a abranger;

c) a criação ulterior, também por Decreto Executivo, da Comissão Nacional Executiva do Plano, cuja organização deverá ser pautada nos moldes da administração do Plano Salte;

d) a assinatura de Convênios nos quais fique estabelecida, tanto quanto possivel, a descentralização administrativa mitigada, reservando-se à União ou ao Estado a orientação e contrôle técnico dos respectivos projetos, de modo que se ressalve a aplicação dos recursos na forma prevista pela presente Lei e atos que lhe forem subseqüentes ou complementares;

e) a votação das leis especiais que a execução ou o alargamento do plano vier a requerer, atendidos os fundamentos que presidem a execução do Plano Salte; e 
f) a formulação do projeto do Plano (Lei Especial de Programa) pela Comissão Nacional Organizadora do mesmo, a fim de que seja encaminhado ao Congresso para votáção à parte, integrado pelas tabelas discriminativas das obras, serviços e demais empreendimentos a serem atendidos.

$\S 2$. O projeto referido na alinea " $f$ " do parágrafo anterior deverá conter:

a) a consignação de recursos para o início e desenvolvimento, até conclusão, de obras e serviços públicos imprescindiveis às áreas municipais, especialmente no setor rural;

b) a consignação de recursos para o prosseguimento ou a complementação de obras e serviçcs públicos existentes nos municípios, e a êstes pertencentes; ou de outros objetivos, executados pela União, cuja entrega às administrações municipais será feita na forma e nos têrmos que a lei determinar;

c) a consignação de recursos para serem entregues, a titulo de auxílio, às entidades privadas, cujas finalidades digam respeito a serviços de educação e saúde ou prestaçäo de assistência social a título gratuito; bem como a serviços cooperativos, se destina a obras de melhoramentos ou ampliação de imóveis; ou aquisição de equịamentos e instaıações, segundo programa qüinqüenal prèviamente estabelecido para inclusão ao Plano objeto da presente lei;

d) a consignação de recursos para estudos, projetos e respectiva implantação de reformas administrativas destinadas a racionalizar o aparelho administrativo das Prefeituras, incluindo-se nas mesmas a de reorganização dos serviços de secretaria das Câmaras de Vereadures, bem como a formulação de anteprojetos de leis e regulamentos destmados a suprirem deficiências ou a aperfeiçoarem as atividades municipais;

e) a consignação de recursos para o estabelecimento, em larga escala, do sistema de revenda de materiais e equipamentus agrícolas aos pequenos lavradores, por intermédio das Prefeituras ou aas entidades cooperativas locais, mediante a assinatura de convêtrios especiais com a União e o Estado.

f) a consignação de recursos para a concessão de "bôlsas de estudo" às administrações municipais para a formação, tspecialização e aperfeiçoamento técnico-profissional, concernente ao trabalno na agricultura, indústria e comércio; para a formação, especialização e aperfeiçoamento de pessoal destinado a centros, hospitais e demais serviços de saúde; estabelecimentos de ensino rural de qualqı:er natureza, mediante a assinatura de acôrdos especiais entre a União. o Estado e os Municipios ou dêstes com as entidades competentes das órbitas nacional e regional de govêrno: $e$

g) a consignação de recursos para a execução de melhoramentos urbanos, desde que vinculados à saúde e higiene das populações.

Art. 14. Os recursos para quaisquer serviços, obras ou empreendimentos convencionados serão sempre concedidos nas proporções de $90 \%$, $70 \%$ e $50 \%$ por parte da União, e os restantes $10 \%, 30 \%$ e $50 \%$ como contribuições do Município ou do Consórcio de Municipios.

$\S 1^{\circ}$ A. lei concernente ao Planc, referida no artigo $13, \S 1^{\circ}$, alínea "f", fixará as proporçōes estipuladas neste artigo tomando por base as 
seguintos prioridades para maior contribuição da União em relação a cada projeto:

a) maior rentabilidade;

b) maior interêsse econômico, nacional, regional, ou municipal;

c) maior interêsse social; e

d) menor renda municipal.

$\S 2^{\circ}$ As contribuiçốes co Município poderão ser estabalecidas nos respectivos convênios sob formas que vião a financeira.

§3? Os Estados, se assim o entenderem, poderão aderir técnica e financeiramente aos objetivos do presente Plano, especialmente na parte relativa ros empreendimentos, obras e serviços intermunicipais cujas proporçñes venham a exceder à capacidade de contribuição das áreas municipais interessadas.

Art. 15. As obras e serviços públicos a que se referem as letras a), b) e g) do $\$ 22^{\circ}$ do art. $13 \S 2^{\circ}$ sãc as seguintes: .

a) rodovias, inclusive obras de arte, desde que não previstas nos Planos Rodoviários Nacional e Estaduais e destinadas a ligações intra ou intermunicipais, neste último caso à base de prévio acôrdo entre os interessados, isto é, os Municipios membros cie um Consórcio, ou de Consórcios vizinhos;

b) centros, hospitais e demais serviços de saúde pública;

c) postos, núcleos agropectuários e demais serviços relacionados com o melhor aproveitamento das riquezas vegetal e animal;

c) obras e serviços relacionados com a pesca e melhoria das condições de vida dos pescadores e de suas familias:

e) pequenas unidades industriais destinadas a promover o beneficiamento ou maior aproveitamento econômico da produção local;

f) providếncias relacionadas com a proteção dos trabalhadores que se dedicam a atividades extrativas em condições de desassistência patronal e perigoso isolamento social;

g) construção de pequenas usinas de produção de energia para consumo local ou de algumas áreas mnnicipais, neste último caso à base de prévio acôrdo entre os interessados; irrigação;

h) construção dï açudes, barragens, reprêsas, obras e cisterna de

i) obras de saneamento, desobstrução e limpeza de rios, construção de canais;

j) construção e instalação de escolas, especialmente rurais, inclusive promcção de cursos avulsos, para a formação de profissionais: e

k) obras e serviços de águra e esgotos, bem como do saneamento de áreas urbanas e suburbanas.

Art. 16. A municipalização de serviços é princípio dominante na organização dos projetos do Plano e fundamento para a transferência de serviços à alçada das Prefeituras.

Art. 17. Para o efeito do Plano são "beneficios de ordem rural" os destinados à melhoria não só das condições de vida das populações de 
campo como da produção agricola, mesmo nas áreas urbanas e suburbanas das sedes e dos distritos municipais.

Art. 18. As aquisiçõts de materiais e equipamentos para revenda aos pequenos agricultores serão feitas por encomendas globais da Administração do Plano entregues às Frefeituras ou entidades cooperativas locais, conforme programas prèviamente estabelecidos nos convênios especiais firmados com a União e o Estado.

Art. 19. A adesão do Municipio ao Plano importa na aceitação das bases e diretrizes desta Lei bem como dos principios fundamentais, normas e processos estabelecidos nas que se lhe seguiren.

Art. 20. Fica o Poder Executivo autorizado a organizar os projetos relativos aos instrumentos legais ou convencionars, mencionados no $\S 1^{\circ}$ do artigo 13, bem como a baixar os atos de constituição da Comissão Nacional Organizadora do Plano, objeto da alinea a) do mesmo parágrafo e artigo.

Art. 21. A Conissão Nacional Orģanizadora do Plano será constituida de cinco (5) membros e de um assessor principal nomeados por decreto do Presidente da República, sendo que o último, por indicação. em lista tríplice da Associação Brasileira de Municipios.

Parágrafo único. $\mathrm{O}$ assessor principal reunirá a qualidade de diretor executivo da Comissãc.

Art. 22. Fica autorizada pelo Ministério da Justiça e Negócios Interiores a abertura do crédito de $\operatorname{Cr} \$$ 3.000.000.000,00 (três bilhões de cruzeiros) em cada um dos exercicios de 1957 e 1958. As respectivas importâncias destinar-se-âc a custear os trabalhos da Comissão Nacional Organizadora do Plano, o lançamento imediato do esquema de emergência para os empreendimentos mais urgentes, segundo proposta das Câmaras Municipais, com a seleção e aprovação por decreto do Poder Executivo, e ao custeio de execução normal da "Operação Município" no ano de 1957.

$\S 1$ Para a cobertura dêsses recursos bem como das rubricas orçamentárias e de quaisquer outros créditos que no desenvolvimento da "Operação Municipio" se fizerem necessários na conformidade do plano aprovado, é o Poder Executivo autorizado a efetuar emissões de papel moeda, mas sob precisas condições de resgate por meio de empréstimo interno que prevê o artigo $25 \S 2^{\circ}$.

$\S 2$. Os créditos ou receitas da "Operação Município" se aplicarão "in totum":

a) com prioridade absoluta no resgate das emissões de papel moeda feitas para o firn da "Operação Municipio", quanto à parte não coberta pelas emissões de apólices previstas no art. $25, \S 22^{\circ}$;

b) enı seguida, para resgatar as apólices do Empréstimo "Operação Municipio".

Art. 23. Como principal recurso de financiamento permanente, por parte da União, da recuperação municipal, a iniciar-se com o primeiro piano 
qüinqüenal da «Operação Municipio», fica criado o impôsto de «Giro bancário:, regulado na forma dos parágrafos seguintes:

$\$ 1$ : O irapôsto de Giro Bancário, prèviamente regulamentado por decreto do Poder Executivc, computar-se-á no Orçamento da Receita de 1957 (art. 141, § 34, da Constituição) e 'serà cobrado a partir de 1 ? de janeiro de 1957, sob a forma de sêlo ou papel selado, na proporção de dois cruzeiros por milhar de cruzeiros ou fração superior à metade dessa importância, sôbre o valor dos recebimentos e pagamentos, ou ordem de cobranşa ou pagamento, que realize Banco ou Casa Bancária por suas matrizes, sucursais e agências. O tributo aplicar-se-á distintamente às diferentes fases da movimentação dos valores bancários circulantes a qualquer título e sob qualquer forma: (depósitos, pagamentos ou recebimentos, cheques, transferências ou outra).

$\S 2$. Os recursos previstos no presente artigo serão levados à Caixa Nacional de Fomento Agropecuário e Industrial nas Áreas Rurais (Caixa "FAPIAR"), por meio de conta vinculada aberta no Banco do Brasil.

§ 3 À Caixa "FAPIAR" é dado o destino de assegurar a normal liquidação dos financiamentos proporcionados pela "Operação Municipio", independentemente da imediata reprodutividade das Obras, Empreendimentos e Serviços que aquela operação tem por fim custear.

$\S 4^{\circ}$ Ao têrmo do sexênio a que se referem o "esquema de emergência" e c "plano básico" da "Operação Municipio", as disponibilidades da Caixa «FAPIAR» (compreendənndo a contribuição federal prevista neste artigo, bem assim as amortizações e juros dos empréstimos aos Municípios já em fase de liquidação) serão destinados, depois de resgatadas as emissões ou empréstimos que a "Operação Municipio" exigir (art. 22 §§ 1 . e 2\%), ao financiamento de sucessivos "planos qüinqüenais", para melhoria e valorização da vida ruro-municipal brasileira.

$\S .5^{\circ}$ A distribuição dos recursos a que se refere o parágrafo precedente se fará segundo critérios uniformes e bem controlados, pelos quais fiquem atendidas as diferenciaçóes decorrentes da maior ou menor onerosidade dos encargos que enfrentarem os diferentes Municipios, segundo ponderaçáo simultânea dos dois fatôres necessàriamente intervenientes a extensão territorial, de um lado, e a massa demográfica, do outro lado.

Art. 24. No últime ano do qüinquiênio a que se refere o "plano básico" da "Operaçẩo Municipio", e depois em continuação segundo o mesmo critério, formando una cadeia ininterrupta de planos qüinqüenais, se elaborará, sempre na conformidade do prescrito para o primeiro plano, um novo projeto para o qüinqüuenio imediato.

$\S 1$ ? O financiamento dos planos da "Operação Municipio" que se sucederem ao primeiro será projetado salvo o que determinar lei especial de acôrdo com os recursos permanentes previstos nesta lei e então disponíveis on esperados.

$\S 2^{\circ}$ Depois de atendido o disposto no art. 22 e seus parágrafos os recolhinientos que receber a Caixa Nacional de Fomento Agropecuário e 
Industrial nas Áreas Rurais (Reserva ou Caixa "FAPIAR") atinentes a cada exercício serão levados a conta de disponibilidade financeira da "Operação Município" para o exercicio seguinte.

$\S$ 3. Depois dos dois primeiros exercícios, o de 1956 (plano de emergência) e o de 1958 (início do Plano Qüınquienal) da "Operação Municipio", cujo financiamento total caberá a essa Operação promover com os recursos previstos no art. $2^{\circ}$, os encargos das Obras, Empreendimentos e Serviços Municipais no decorrer dos quatro restantes exercícios de primeiro plano qüinqüenal, se aterão ao quantitativo anual de $\operatorname{Cr} \$ 3.000 .000 .000,00$ (três bilhões de cruzeiros). Seu financiamento far-se-á igualmente mediante operações financeiras especiais (emissão de papel-moeda e lançamento de empréstimos) mas já então tais operações terão por fim coibir no fim de cada exercicio apenas a diferença entre o total de três bilhões de cruzeiros e a disponibilidade da Caixa "FAPIAR" para o exercício imediato.

$\S 4$. Liquidados en qualquer tempo os compromissos da "Operação Municipio» quanto às emissões do papel-moeda e de apólices que o seu lançamento houver exigido, os recebimentos resultantes dos respectivos empréstimos reforçarão as disponibilidades da Caixa FAPIAR, que se reunirá aoß ingressos provenientes do impôsto sôbre o Giro Bancário. Ficarão assim constituidas às disponibilidades para os fins dos subseqüentes Planos Qüinqüenais de Obras e Empréstimos Municipais, ressalvado o disposto no $\S 7^{\circ}$ dêste artigo.

§ 5: O segundo Plano Qüinquienal de Obras e Emprendimentos Municipais será estabelecido na base de uma receita anual correspondente ao que fôr apurado, como disponibilidade líquida, no balanço da Caixa FAPIAR para o último exercício do prieiro qüinqüênio. Ficará como reserva, para suprir deficits imprevistos da execução do Plano ou constituir disponibilidade para o plano qüinqüenal imediato, a diferença a mais que fôr efetivamente arrecadada.

$\S 6^{\circ}$ Ao invés, verificando-se insuficiência de ingressos no decorrer do qüinqüênio, quanto ao importe anual das disponibilidades previstas, será feita a emissão progressiva, até o fim do qüinqüênio, de papel-moeda e apólices, permanecendo, porém, as contribuições dos Municipios que foram recolhidas a partir de término do qüinquuênio, vinculadas globalmente ao resgate dêsse compromisso extraordinário.

§ 72 Completado o qüinqüênio do plano básico da "Operação Municipio", os ingressos ou receitas da Caixa FAPIAR não vinculados a compromissos legais ou contratuais e que excederem anualmente o montante de Cr\$ 3.000.000.000,00 (três bilhões de cruzeiros), se aplicarão, metade ao refôrço da própria Caixa e a outra metade ao resgate da divida interna federal.

$\S 8:$ Resgatadas as emissões de papel-moeda que se houverem aplicado ao plano de emergência de 1947, os pagamentos recobidos das Municipalidades em virtude da "Operação Município" serão recolhidos à Caixa FAPIAR, em conta especial. As importâncias arrecadadas terão por destino, 
ao encerrar-sz o exercício, o resgate ao par, mediante sorteio, das apólices em circulação que lastrearem a emissão inicial.

$\S 9^{\circ}$ Nos contratos dos empréstimos feitos pela Caixa FAPIAR ficará previsto que as contribuições anuais (amortizações, juros e fundo de reserva), não serão inferiores ao mínimó, aqui preestabelecido, de $1 / 30$ do débito total, independentemente do, que renderem as obras ou serviços executados. Ficará o deficit, se houver, a cargo da receita ordinária do Municipio; o saldo, quando existir, se computará como receita municipal extraordinária.

$\S 10$. As taxas, impostos ou créditos quaisquer que forem instituídos para financiar as obras, serviços ou empreendimentos executados com o auxílio da "Operação Município" serão majorados de $20 \%$ do importe calculado para o custeio das obras, serviços ou empreendimentos, compreendendo a amortização do capital e juros, tendo êstes por limite a taxa máxima de $6 \%$. Desde o iuício da sua arrecadação, e durante quinze anos, a receita da majoração aqui prevista será recolhida ao Fundo de Reserva da Caixa FAPIAR, destinada a permitir, à custa dos melhoramentos já propiciados aos Municipios, o progressivo alargamento, com recursos de origem municipal, dos programas a que se ativer a "Operação Municipio" nos qüinqüênios subseqüentes.

Art. 25. A operação financeira destinada a custear as obras, serviços e empreendimentos compreendidos tanto no plano de emergência quando no plano básico da "Operação Municipio", obedecerá fundamentalmente ao esquema firmado nos parágrafos dêste artigo, independentemente das medidas de segurança ou complementares que a Comissão Executiva do Plano propuser e o Govêrno aprovar.

§ 10 Aprovado o plano de emergência, cujo financiamento será previsto em cotas mensais predeterminadas, a emissão de cada cota será feita e levada à respectiva conta 10 Banco do Brasil, até o dia dez de cada mês.

$\S 2^{\circ}$ A emissão de cada uma das cotas terá o lastro de uma emissão especial de apólices intituladas "Operação Municipio", ao juro de $9 \%$ ao ano, as quais serão tomadas e resgatadas (por sorteio) ao par.

$\S 3^{\circ}$ Os ingressos resultantes da venda das apólices da "Operação Municipio", serâo incinerados, como resgate prograssivo das emissões de papel-moeda a que tais apólices servirzm de lastro.

$\S 44^{\circ}$ Dara o financiamento da "Operação Município" a partir de 1958 , no caso de insuficiência dos recursos já então existentes na Caixa FAPIAR, fica autorizado um empréstimo compulsório a ser lançado por decreto executivo dus contribuintes (pessoas físicas ou jurídicas) do impôsto sôbre a renda. Esse empréstimo se efetivará em cinco prestações anuais cada uma na proporção que fôr fixada mas não superior a $10 \%$ da importância devida pelo contribuinte (excluído o adicional a que se refere o $\$ 6^{\circ}$ do art. 38).

$\S 5^{\circ}$ Os contribuintes do impôsto sôbre a renda como credores dêsse empréstimo receberão uma "fôlha de crédito" onde será registrado o Competente movimento atribuindo-1he o juro de $5 \%$ ao ano. 
$\S 6$ O O resgate dêsse empréstimo e o pagamento dos respectivos juros se fará a partir to exercício imediato ao recebimento da último anualidade recolhida e mediante descuntos sucessivos sôbre a importância que os contribuintes do impôsto sôbre a renda houverem de pagar cada ano ao Tesouro. Tais descontos se farão por cotas correspondentes a cinco por cento (5\%) da contribuição principal (sem os adicionais) do mencionado impôsto até liquiidação.

$\S 77^{\circ}$ Como encargo decorrente da "Operação Município" o Orçamento Federal depois de lançado o empréstimo compulsório previsto no $\S 4$ iêste artigo só responderá em cada exercício do primeiro Plano Qüinqüenal pela importância necessária para completar-se o importe anual da mesma operação (Cr\$3.000.000.006,00), levando-se em conta os recursos específicos previstos no art. 23. Nos exercícios subseqüentes, o orçamento federal, apenas incluirá verba para suprimento da Caixa FAPIAR até o limite da importância que fôr estiniada necessária a fim de que os recursos anuais disponiveis para assegurar continuidade à "Operação Municipio", não venham a ser inferiores a Cr\$ 1.000.000.000,00 (hum bilhão de cruzeiros).

$\S \delta$ ? Ocorrendo qualquer saldo do empréstimo compulsório previsto no $\S 4^{\circ}$, será incinerada a respectiva importância, a título de refôrço do resgate da emissão monetária inicial. Não havendo mais responsabilidades dessa espécie, o saldo se aplicará a retirar da circulação, mediante sorteio, as apólices cuja tomada já houver resgatado parte das emissões de papel-moeda inicialmente efetuadas para financiamento da "Operação Município"; ou então se tal resgate já estiver concluído, no refôrço das reservas da "Operação Municipio", podendo destinar-se, no próprio qüinqüênio em curso, a empreendimentos especiais e urgentes que interessem a dois ou mais Consórcios ainda subdesenvolvidos.

\section{CAPÍTULO III}

\section{Da Cosperação Intermunicipal}

Art. 26. Por fôrça do principio básico firmado no art. $7^{\circ}$ desta lei, fundamento do "Plano de Cooperação Intermunicipal" assentado no art. 6? alinea " $b$ ", a habilitação preliminar das Municipalidades aos benefícios previstos na "Operação Município" far-se-á "in solidum" e globalmente.

$\S 1^{\circ}$ Entender-se-á esta solidariedade com referência aos grupos ou consórcios de vizinhanças que os Municípios instituissem entre si, com a finalidade e sob a forma liminarmente definidas nos arts. 10 e 11 da presente lei.

$\S 2$ Os Consórcios Municipais visam ao efeito e eficiente estabelecimento da cooperação técnico-administrativa no plano da convivência internacional, e, ainda, entre tais associações de Municipios e os diferentes órgãos da administração federal e estadual que carecem de atuar mediante descentralização sub-regional, mas em condições de poderem planificadamente, e em perfeita solidariedade com as administrações locais co-interessadas, beneficiar por igual aos Municipios Unidos em que se verificar a respectiva associação. 
Art. 27. Organizar-se.ão tais Consórcios, satisfeitas as condições legais, entre os Municipios das áreas geográficas a êsse fim predeterminadas, como circunscrições constitutivas das sub-regionais (já efetivamente municipalizados ou ainda a municipalizar, em parte) definidas nesta lei.

§ 1: A formação de cada Consórcio assegurarâ a êste personalidade jurídica como ente autárquico paraestatal. Deverá processar-se mediante acôrdos multilaterais entre os Governos Municipais compactuantes do Con* sórcio, os quais serão representados pelos próprios Prefeitos e na forma das autorizaçôes formuladas pelas respectivas Câmaras de Vereadores.

$\S 2$. Os acôrdos ou Cartas Estatutárias que declarem instituídos os Consórcios Municipais na forma e para os fins da presente lei, adotarão uniformemente, sern prejuizo de suas cláusulas específicas, e além do que prescreverem as disposições constitucionais e a competente legislação orgânica, as diretrizes, normas e bases gerais necessárias para que se estabeleça com eficiência, na prática administrativa, a solidariedade nacional subentendida nos princípios adotados em favor do revigoramento dos Municipios, e que é urgente : instantâneamente reclamada pelos vitais interêsses da Nação.

Art. 28. A organização dos Consórcios Municipais se verificará, em tôdas as Unidades da Federação, de modo geral e uniforme quanto às características fundamentais que os habilitem, por via da livre determinação dos Municípios, aos fins sócio-econômicos e judiciário-administrativos aqui previstos.

$\S 1$ 2 O Consórcio Municipal tem por objetivo, conseqüentemente, obter no que fôr a isşo essencial qua a Nação se capacite a promover de modo efetivo e orgânico, e tanto em extensão quanto em profundidade, o seu próp:io desenvolvimento. Essse desenvolvimento processar-se-á, todavia, segundo esquemas e programas que tendam a suprir as atuais deficiências e necessidades da rida nacional quanto aos seus planos superiores, em decorrência, precisamente, das condições negativas os deficitários, que ora detêm, amortecem ou incapacitam a vida municipal.

¿2 O esfơrço de propulsão da vida municipal, configurado e definido neste artigo, apoiar-se-á principalmente na imediata instituição e desenvolvimento intensivo de um qt:adro metropolitano interior, de sentido sub-regional. Tal quadro será a êsse fim planificadamente predisposto, mas sob a condição de proporcionar efetiva cobertura a todo o território nacional.

$\S 3$ ? O quadro de núcleos interiores bem organizados e efetivamente predispostos ao progresso, a qua se refere êste artigo, é o que, sem favorecer o urbanismo anti-ruralista nem quaisquer outras deformações viciosas, mas na posse real de todos os recursos de civilização e irradiando normalmente poderosa influência de maneira equiitativa por sôbre o território jurisdicionado venha a ser integrado por aquelas cidades-chaves, tôdas elas ligadas entre si e com as cidades dos Municipios associados, que ficarem servindo de sedes aos diferentes grupos cooperativos formados pelos "consórcios" de unidades municipais.

$\S 4$. A organização dos Consórcios Municipais subentenderá que, em favor de plena capacitação sócio-econômica e administrativa dos centros urba- 
nos escolhidos como sede da assistência mútua entre os Municipios Unidos e conseqüente atuação metropolitana, se empregarão de forma prèviamente planejada, e sob critérios de eqüitativa distribuição, todos os esforços e instrumentos de ação das três órbitas do Poder Público - a nacional, a regional e a local.

Art. 29. As Unióes convencionais de Municipios, ou Consórcios Municipais, isfo é, realizados "entre Municipios", deverão:

a) abranger, com área média ponderadamente assentada para cada região, nãc menor de $10.000 \mathrm{~km} 2$, nem superior a $50.000 \mathrm{~km} 2$, todo o territóri, nacional, de maneira que fiquem interdistanciadas sob condições convenientes as respectivas sades, em cada uma das Unidades da Federação, assegurando pràticamente, dessa forma, a efetiva coesão da vida nacional;

b) servir de ponto de apoio, de modo tanto quanto possivel equivalente em tôda a extensão do país, à organização e expansão agrária brasileira, mas em condições de garantir além da efetiva proteção a bens e vidas, o gôzo e exercício da cidadania nivel condizente de bem-estar social e econômico, o satisfatório desenvolvimento cultural, para as respectivas populações, tanto urbanas como rurais;

c) propiciar pela cooperação intermunicipal e com o auxilio efetivo da União e dc. Estadc, as obras, serviços, empreendimentos e iniciativas que, por igual, dotem os Municipios Unidos com os recursos da civilização e a necessária capacidade de progresso mas obedientemente a bem estabelecidos critérios, tal como é requerido pelo papel que à vida comunal cabe desempenhar na fundamentação e desenvolvimento da vida estadual e nacional.

Art. 30. Os benefícios do progresso e da civilização a conduzir para o interior brasileiro, mercê das energias e recursos que se conjugarem com o objetivo de assim melhor se aplicarem em larga escala nas cidades-sedes dos Consórcios Municipais, se desenvolverão, por isso mesmo, em forma convergente e solidária, tendo por fim:

a) caipacitar as metrópoles sub-regionais, tão cedo quanto possivel, para a sua alta missão civilizadora, mas sem deter ou enfraquecer antes estimulando- $\mathrm{c}$ e favorecendo-o - o progresso das demais cidades vinculadas an Consórcio, de sorte que tais centros metropolitanos ou cidadeschaves de zonas se tornem as necessárias "bases de operações" para as medidas governativas tomadas a fito de promover desde logo em condições reais tanto de eficiência quanto de suficiência, a efetiva ocupação do território nacional e a assistência devida às comunidades municipais;

b) conduzir as populaçöes municipais, por igual, e ao mesmo tempo, a um tipo de satisfatória estrutura agrária e industrial (Operação Municipio);

c) elevar a um padrão condigno de bem-estar social e econômico, tanto os habitantes dos núcleos urbanos quanto os contingentes que povoem distribuidos, em cada Estado ou Território, segundo as sub-regióes especifiou extrativos - (Operaçâc Município). 
Art. 31. Os Municipios brasileiros, para os fins desta lei, ficarão distribuidos, em cada Estado ou Território, segundo as sub-regiões especificanrente delimitadas pelos Conselhos Nacionais de Geografia e de Estatística, en! deliberação comum.

$\S \cdot 1^{\text {Q }}$ A distribuição prevista neste artigo terá por objetivo traçar de modo sistemático e complexo geopolitico que, completando e complementando o parcelamento territorial primário da República, visará manter-lhe ao mesmo tempo a plena potencialidade sócio-econômica.

$\S 2$ : $O$ esquema geopolítico (ou divisão sub-regional) a estabelecer para os fins dêste artigo apoiar-se-á apenas aos critérios de vizinhança geográfica, relativa equivalência territorial e facilidades de intercomunicações (já estabelecidas ou a estabelecer). Não haverá, portanto, a intenção, que é contra-indicada ao caso, de obter-se a homogeneidade de aspectos geográficos ou característicos econômicos; considerar-se-á o país como um todo, para o fim de se the assegurar circunscricionamento racional, sem destoantes disparidades de magnitude quanto à área, nem diformes configurações, mas aó mesmo tempo, e tão sòmente, — adstrito à divisão politico-federativa da República.

$\S 3^{\circ}$ Os Conselhos Nacionais de Geografia e de Estatística elaborarão o projeto a que se refere o presente artigo, depois de ouvidos os seus órgãos regionais, entidades já credericiadas que são, para trabalhos dêsse gênero. Tal enrargo os sobreditos Conselhos o executarão na sua qualidade representativ.t, por fôrça da Convenção Intergovernamental de 1936, da solidariedade entre a União, os Estados e os Municipios quanto a tudo que disser respeito às atividades e realizações técnicas relacionadas com a Geografia e a Estatística.

§ 4. A Carta Estatutária que resultar da Convenção Internacional instituidora de cada Consórcio será elaborada e firmada consoante a forma e os principios gerais previstos nesta lei para fins de sistematização, acrescidos, porém, se assim os Municípios interessados julgarem necessário, de normas específicas. Tais normas ficarão assentadas nas autorizações legislativas das Câmaras de Vereadores, onde se fará também preliminar referência - a fim de que prevaleçam estas expressamente e sem discrepâncias como disposições orgânicas - às "normas, diretrizes, bases e fundamentos" constantes do presente diploma legislativo para o quar como abreviatura utilizável em tal referência fica adotado o simples indicativo de "Lei Pró-Município".

§ $5^{\circ}$ C quadro geográfico dos Consórcios só será modificável decenalmente depois de promulgadas e executadas as leis qüinqüenais revisoras da divisão municipal. Os desdobramentos dos Consórcios só serão decididos, por conseguinte nos anos de milésimo nove, para entrar a modificação em vigor a $1^{\circ}$ de marçi dos anos de milésimo zero, em correspondência com as medidas preparatórias dos Recenseamentos Gerais da República. A revisão referida sera assim medida preliminarmente ao levantamento geral e periódico das caracteristicas demográficas e sócio-econômicas brasileiras. E' reconhecido que tais operações devem ser efetuadas decenalmente em todo o pais, segundo plano uniforme, mas que só atingirão a pleno efeito os seus 
fins se foreın realizados por sôbre um quadro territorial bem definido, e também estabilizado, tanto na extensão como nas categorias adequadamente ordenadas.

$\S 6^{\circ}$ O desdobramento do Consórcio se efetivara mediante ato revocatório ou rescisório assentado entre os Municípios associados. Nesse ato declarar-se-á antiga unidade que as novas forem chamadas a substituir, conforme à deliberação solidàriamente tomada pelas circunscrições municipais co-interessadas. Os Municípios, assim, são livres de modificar numa certa medida e coni oportunidade seus vínculos associativos, mas sem quebra no princípio de ordem e equilibrio que se houver implantado com alcance e sentido nacional.

$\S 7^{\circ}$ Sob pena de ficarem sustados os benefícios desta lei, o desmembramento de qualquar Consórcio só será objeto de exame e deliberação quando, sendo a respectiva área superior a $20.000 \mathrm{~km} 2$, convierem unânimemente seus componentes em que se desdobre o antigo Consórcio em dois, entre os quais, ficando-lhes assegurada relativa equivalência territorial, se distribuam os Municipios que o compuserem.

$\S 8^{\circ}$ O desdobramento far-se-á sem que qualquer das unidades consorciais resultantes se veja privada de continuidade territorial; mas não poderá nenhuma delas ficar com área inferior a dez mil quilômetros quadrados, mesmo quando, para conseguir-se essa equilibrada divisão geográfica se torne preciso prever a criação, no Consórcio, de novos Municípios ou Territórios Municipais.

Art. 32. Por meio do quadro associativo dos Consórcios Municipais fixar-se-á o sentido coniplementar do "Quadro Municipal" da República em face da autonomia dos Estados-Membros, propiciando pràticamente aos $\mathrm{Mu}$ nicipios, também êles necessária e constitucionalmente autônomos, os mesmos benefícios que decorrem da existência da União Federal para os Estados Federados: isto além da assistência e ajuda que os Municípios Unidos também ficam habilitados a receber, em melhores condições, do Govêrno Federal.

Art. 33. E assentacio expressamente o principio de que não se infirmará pràticamente, em nenhuma hipótese, a autonomia municipal, nem se deixará sem proteção equânime o patrimônio municipal expresso em área geográfica e possibilidades financeiras, a cuja proteção se destinam, na Carta Politica, os arts. $7 .^{\circ}$, inciso VII, alinea «e» e $141, \S 38$, prescrevendo o primeiro até mesnıo o instituto preservativo da intervenção federai, e permitindo o segundo o procedimento judicial de defesa, por iniciativa de qualquer cidadão.

§ 1. O princípio firmado neste artigo há de conciliar-se com a necessidade de concederem os Estados a autonomia municipal a novas áreas dos respectivos territórios já suficientemente desenvolvidos. Essa medida ficará neutralizada, no seu efeito de debilitação dos Municípios desmembrados, desde que deliberado sob a precaução do estabelecido no parágrafo inediato.

$\S 2 .^{\circ}$ As deliberações sóbre a criação de novos Municipios serão tomadas sem afetar nem a área territorial do Consórcio nem também, conse- 
qüentemente, suas possibilidades econômicas. Também não admitirão nem que se retirem aos Municipios, objeto de desmembramento, as condições nirimas de subsistência e progresso, nem que se criem novos Muricipios desprovidos dessas mesmas condições, ainda que respeitados os dema1s requisitos legais.

§3. A formação dos Consớcios implicará ainda a caractevização da cidade em que houver cie ter sede o Conselho Administrativo da União Municipal como ponto-chave da sub-região, conforme a fundamentada indicação concorde dos Conselhos Nacionais de Estatística e de Geografia .

$\S 40^{\circ}$ Em benefício das cidades que forem constituídas sedes de Consórcios, e conseqüentemente ao destino que lhes é reservado, se promoverá o duplo movimento:

a) de convergência dos recursos e esforços que devem mover as atividades e a solidariedade intermunicipal de sentido sub-regional; e

b) complementarmente, 'de descentralização com idêntico sentido, das atividades, serviços e recursos da Uniâo e dos Estados, no que tange a tudo quanto deva ter alcance nacional mas se realize através de atuação direta em tôda a extensão geográfica do país, distribuída esta segundo o seu quadro básico -- o da divisão nunicipal, - em o qual se devem apc:ar todos os demais circunscricionamentos necessários à organização e proteção do corpo social cia Nação.

$\S 5 .^{\circ}$ Constituem objetivo nacional impreterivel quanto aos esforços de recuperação e reajustamento da vida racional, no seu sentido de unidade, harmonia econômica (equilibrio) e ética, politica (justiça), fazer-se evoluir o quadro municipal e brasileiro na direção da melhor distribuição dos benefícios e encargos resultantes do espaço geográfico. Será êste o meio para que se corrijam as atuais e injustificadas preferências em favor de determinados Municipios e em detrimento de cutros, as quais, assim, ficarão expressamente evitadas, consoante o disposto no art. 31 , inciso I, da Constituição.

\$.$^{\circ}$ Onde, em conseqüência, o território ainda fôr despovoado, aí acumular-se-ão preferencialmente os recursos de povoamento e organização, em regine administrativo especial (art. 156 da Carta Constitucional). Esse regime administrativo preparará a respectiva autonomia mas de acôrdo com um padrão regional que não se constitua anomalia dentro das condiçõe: de variabilidade ponderadamente estabelecidas a fim de - e em condições eqüitativas - poder o progresso beneficiar em breve prazo todo o território da República.

§7. Instituida e delimitada na Carta Estatutária de Consórcio, a solidariedade de ação técnico-adminisirativa entre os Municipios Unidos, será tal solidariedade, mediante expressa cláusula do diploma convencional, efetivamente estabelecida e dirigida por um Conselho Administrativo. Ficará - Conselho constituído pelos titulares das respectivas Prefeituras, cabendo a Presidência ao Prefeito do Municipio sede do Consórcio. Ao Presidente do Conseiho Administrativo incumbirá assim, em nome e por delegação daquele alto Colégio, exercer permanente vigilância sôbre os respectivos órgãos executivos - 0 administrativo $e$ o técnico - na forma precisa da del beração coletiva e partidária das Prefeituras co-vinculadas. 
§ 8. As Cartas Estatutárias também proverão à suplência dos membros dos respectivos Conselhos Adrinistrativos, a qual deverá ser atribuida, segundo a hierarquia política implícita na conceituação da autonomia municipal, aos Presidentes das respectivas Câmaras de Vereadores.

§ 9. No Estatuto cu Carta Estatutária do Consórcio, ficarão previstos, como instrumentos de ação dos Municipios Unidos, a Secretaria do Conselho Administrativo e o Departamento Técnico Intermunicipal de Obras e Emipreendimentos. Tais órgãos serão crganizados ulteriormente pelo sobredito Conselho, quando os puser a funcionar por meio de Resoluçóes (com numeração seguida e uma para cada assunto) conforme a experiência e as circunstâncias que resuitarem da movimentação dos serviços do Consórcio.

$\$ 10$. No Estatuto de cada Consórcio se incluirá, como garantia de eficiência para o sistema cooperative a estabelecer em tôda a Republica, a prescrição de serem escolhidos, quet o Secretário do Conselho Administrativo da União, quer o Chefe do Departamento Técnico Intermunicipal de Obras e Empreendimentos, sob a condição de que os respectivos titulares possuem diploma profissional de nível superior. Essa capacitação deverá decorrer de qualquer um dos cursos, de Ciências Administrativas, Jurídicas, Sociais, Estatísticas, Contábeis, - de preferência de Engenharia Agronômica - quanto ao Chefe do Departamento Técnico.

§ 11. A Carta Estatutária de cada Consórcio assentará a instituição de uma Caixa própria para o respectivo financiamento, constituída com os recursos de qualquer origem que ao Consórcio forem distribuidos; mas sob a condição de ficarem êsses recursos rateados pelas contas gerais que convier criar, vinculadamente aos fins principais da União Municipal na conformidade da competente Resolução Orçamentária do Conselho Administrativo da autarquia intermunicipal .

$\S 12$. Complementarmente, estipularão os Municípios Associados, como recursos disponiveis do Consórcio, para os fins estipulados na conformidade do Orçamento Anual que será fixado pelo respectivo Conselho Administrativo, os seguintes:

1. A metade da cota do Impôsto sôbre a Renda que a cada um competir. A importância total dessa cota, para os Municípios de cada Consórcio, será depositada anualmente pelo Ministério da Fazenda na Agência do Banco do Brasil localizada na sede do Consórcio, à disposição do Conselho Administrativo dêste. O depósito será feito em duas prestações: a primeira, a título de antecipação de receita, se fará no primeiro mês do exercício, correspondendo à metade da importância global estimada; a segunda se constituirá pela efetiva parte restante, devendo efetuar se no sétimo mês do exercício. O Presidente do Consórcio transferirá aos Governos dos Municípios associados a parte da cota não vinculada ao custeio dos serviços do Consórcio.

2. As cotas distribuidas na respectiva forma contratual, como financiamento das Obras, Empreendimentos e Serviços previstos no plano da «Operação Município» e em execução nas Unidades Associadas, mas cujo emprêgo se aterá aos critérios de opção, prioridade e distribuição assentados pelo Conselho Administrativo da União Municipal. 
3. O importe dos auxílios especiais com vinculações preestabelecidas e resultantes de leis da União, do Estado ou dos Municípios associados; ou, ainda, os recursos decorrentes de Convênios multilaterais, acôrdos bilaterais ou operações de crédito que o Consórcio representado pelo Presidente do Conselho Administrativo e na forma das competentes autorizações legais e convencionais, vier a realizar.

$\S 13$. Será assentada como norma fundamental pelos Municipios Unidos, a elaboração anual do orçamento do Consórcio para o exercício seguinte. Adotar-se-á o critério fundamental de que êsse orçamento deva fazer a distribuição da totalidade dos recursos disponiveis, desdobrando sua aplicação em rubricas discriminadas segundo os Municipios beneficiários dos melhoramentos a realizar.

§ 14. Quando para essa distribuição não fôr preferido o critério de cotas iguais por Municipio, adotar-se-ão coetas que resultem da dupla divisão proporcional, isto é, levándo em conta, em adequada ponderação, de um lado a extensão territorial, e de outro a população, ambas consideradas como fatôres que devem graduar conjugadamente o esfôrço em prol do desen volvimento local.

$\S$ 15. Assentarão, bem assim, as Uniões Municipais que os orçamentos do Consórcio devam discriminar as verbas que houverem de custear obras e empreendimentos de comum interêsse das Municipalidades consorciadas, quando tais obras e empreendimentos se localizarem em um ou alguns sòmente, dos Municipios Unidos, mas visando a reconhecido ben zfício coletivo para tôdas as unidades municipais associadas.

$\S 16$. Estipularão os Municípios Associados a prioridade daqueles objetivos e melhoramentos que, por serem julgados mais urgentes para a totalidade ou para a maior parte das municipalidades do país, precisam ser preferencial e simultâneamente atacados em tôda a Federação Brasileira, sob pena de ficarem prejudicadás a unidade e a integração dos próprios fundamentos da vida nacional (Operação Municipal).

$\S 17$. Admitirão, em conseqüência, os Municípios Unidos, como ponto de partida de seus comuns esforços, a norma de deverem ter primeira urgência entre os objetivos a que alude o parágrafo precedente, os seguintes (Operação Municíp:o):

1. o levantamento dos mapas municipais com a divisão distrital e completa caracterização das divisas, mediante acôrdo com o Departamento Nacional de Geografia;

2. a provisão de energia (de origem hidráulica, térmica ou eólia) necessária ao desenvolvimento sócio-econômico de cada uma das áreas municipais, mas compreendida cada qual como um todo no que toca às suas necessidades de expansão;

3. o abastecimento de água e luz, bem como os serviços de esgôto sanitário, para os núcleos populacionais de cada município; e, ainda, o fornecimento, em condições de aquisição as mais fáceis e menos onerosas possiveis, dos elementos necessários às residências rurais para que possam tôdas ficar servidas de água potável filtrada, iluminação artificial higiênica e fossas sépticas; 
4. a realização do plano rodoviário intermunicipal, levados em conta, porém, os planos federal e estadual congêneres, e também, mediante acôrdos especiais, a planificação que os Consórcios vizinhos houverem estabelecido com análogos objetivos, visando-se com isto a assegurar o melhor aproveitamento do sistema de comunicações internas e externas do Consórcio, como elemento dinâmico de integração e expansão da rêde rodoviária nacional;

5. as obras indispensáveis de salubrificação e saneamento, tanto rural como na zona urbana, de cada Município;

6. o estabelecimento em cada Municipio, de um minimo de linhas telefônicas que ponham em comunicação imediatamente:

a) a sede municipal, con a rêde de Telégrafo Nacional, (se ainda não houver Agência Telegráfica local);

b) as sedes distritais, com a sede municipal; $e$

c) os povoados, com a sede do respectivo distrito;

7. as obras exigidas pelo desenvolvimento econômico das Unidades Municipais associadas; mas em condições harmônicas, quer entre os respectivos Distritos, quer, igualmente, entre o Consórcio que os mesmos Municipios formarem e as Uniões congêneres vizinhas;

8. A instalação, das unidades industriais necessárias ao suprimento das obras municipais de engenharia, não omitida entre tais unidades, especialmente, uma fábrica de cerâmica e de artefatos de cimento, em corıdições de atender às necessidades do Consórcio quanto aos respectivos empreendimentos técnicos urbanos ou rurais em todos os seus Municipios, sem dependência de abastecimento a ser obtido fora dos seus limites;

9. as realizações de natureza educacional, de assistência sanitária e de serviço social, tanto às populações urbanas quanto aos habitantes das zonas rurais, mas sem privilegiar aquelas em detrimento destas, nem perder de vista a necessidade de inferioridade relativamente aos grupos sociais compreendidos nas Uniões Municipais vizinhas;

10. o combate à formiga e a quaisquer outras pragas, tais como a das lagartas, a dos gafanhotos ou a dos escorpiões; mas em articulação adequada com as iniciativas congêneres dos Consórcios limitrofes, obtidos para tanto, sempre que a intensidade da praga ultrapassar os recursos da administração local, os auxílios do Estado ou mesmo da União, mediante acôrdo com os órgãos especializados competentes;

11. a aquisição, plantio ou preservação das reservas florestais dos Municípios Unidos, bem assim, onde necessário, a criação de um hôrto florestal e de um serviço permanente de reflorestamento, expansão da silvicultura e fruticultura e conservação do solo, destinado a atuar, principalmente, mediante acôrdos com os proprietários agrícolas;

12. o prévio traçado de planos urbanísticos para as cidades $e$ vilas do Consórcio previstos nesses planos os respectivos "cinturões verdes»; mas para tal fim utilizando se acôrdos com o Conselho Nacional de Geografia e outros órgãos federais ou estaduais que a êsse objetivo possam prestar útil concurso; 
13. a modernização e racionalização dos serviços administrativos dos Municipios Unidos, baseando-se tal esfôrço em acôrdos com os órgãos estaduais que nisso puderem colaborar e, especialmente, com o Departamento Administrativo do Serviço Público Federal, a Fundação Getúlio Vargas e o Instituto Brasileiro de Administração Municipal;

14. a propaganda, a orientação e os auxílios necessários às classes rurais dos Municipios Unidos, utilizada a cooperação possivel dos órgãos federais e estaduais para tanto capacitados, no sentido de assegurar a alienação popular barata e em condições higiênicas, dispensada qualquer importação, no que se referir à carne, ovos, laticínios e principais produtos agrícolas (feijão comum e feijão soja, arroz, mandioca, batatas, milho) além da produção hortícola e pomareira que o solo e o clima permitirem.

$\S$ 18. Estipularão ainda os Municipios Unidos as normas básicas para o funcionamento do Conselho Administrativo, fixando-lhe, no minimo, duas reuniões ordinárias: uma, a realizar-se no primeiro dia útil da segunda quinzena de abril, a qual fique especialmente dedicada à tomada de contas dos dois órgãos executivos do Consórcio - o administrativo e o técnico, na conformidade das resoluções normativas prèviamente estabelecidas para o devido contrôle e a defesa dos interêsses dos Municipios Unidos; e a outra, no primeiro dia útil da segunda quinzena de novembro, tendo por especial objetivo a elaboração do orçamento do Consórcio para o exercício seguinte.

$\S 19$. Os Municípios Unidos ainda determinarão, com as competentes sanções, a responsabilidade das autoridades executivas do Consórcio, a saber, o Secretário do Conselho Administrativo e o Engenheiro-Chefe do Departamento Técnico de Obras e Empreendimentos, que somente poderão ser nomeados em comissão ou mediante contrato. Só atuarão os referido3 funcionários dentro das normas estatutárias, legais ou regulamentares, bem assim na conformidade das autorizações especificas do Presidente do Conselho Administrativo; cabendo a êste movimentar os fundos bancários do Consórcio, cujos cheques destinados ao custeio dos respectivos serviços deverão ser conjuntamente assinados por ambas as autoridades delegatárias doš Municipios Unidos.

Art. 34. Os acôrdos que os Municípios Unidos realizarem «in solidum» com o Estado, ou com a União, ou ainda com ambos em conjunto, terão por fim:

a) a ajuda e solidariedade, prèviamente disciplinadas e planificadas, das órbitas superiores de Govêrno a todos os empreendimentos incluidos na competência dos Municipios e que forem necessários ao seu desenvolvimento: constituindo, em conseqüência, contribuição de base para o progresso tanto dos Estados quanto dos Territórios, a importar, assim, igualmente, no progresso de tôda a Federação, mas processado êste em condiçôes, de fato, unitormes e equânimes;

b) dotar prontamente cada sede do Consórcio com os elementos de civilização que lhe forem indispensáveis como centro biodinâmico da respectiva règ ão;

c) levar desde logo, para as metrópoles intermunicipais, os órgãos federais ou estaduais que, ali somente, ou ali em primeiro lugar, quando 
também necessários em algumas outras ou em tôdas as cidades e vilas, precisem agir de forma descentralizada, como requisito essencial-a sua própria finalidade, e para assim jurisdicionar direta e efetivamente ou todo o território dos Municípios abrangidos pelos Consórcios, ou, ao menos, as partes dêsse território para isso mais indicadas (Operação Município).

$\S 1 .^{\circ}$ Será considerado de primeira urgência promoverem os Conselhos Administrativos dos Consórcios, com tôda a fôrça ao seu alcance, na conformidade desta Lei, a localização, no território dos Municípios Unidos, das seguintes unidades, sistemas ou rêdes de serviços ou instituições oficiais ou privadas:

a) A rêde completa das Agências do Instituto Brasileiro de Geografia e Estatística, compreendendo as Agências-Modêlo nas Capitais dos Consórcios, as Agências Municipais, as Agências Distritais, as Agências Territoriais e Subterritoriais e as Agências Especiais; cabendo a essa rêde, além dos seus fins específicos como aparelho incumbido da coleta estatística ou censitária: peciais;

1. os objetivos que resultaram de Convênios interadministrativos es-

2. o cadastro imobiliário;

3. os demais registros rurais, inclusive o Registro Civil (êste último, mediante prévia delegação do Estado ao I. B. G. E.) nas condições prescritas no $§ 10^{\circ}$ do art. 38 da presente Lei;

b) Uma rêde de Agências bancárias que cubra, imediatamente, com as categorias convenientes, tôdas as cidades que forem sedes de Consórcios, estendendo-se, logo se torne possivel, às demais sedes municipais (cidades), bem assim às metrópoles territoriais e subterritoriais (cidades ou vilas);

c) Uma rêde de Caixas Econômicas abrangente de tôdas as cidades. vilas ou núcleos urbanos ou postos que forem sedes territoriais ou subterritoriais;

d) uma rêde de estações rádio-receptoras e rádioemissoras de pequeno alcance, por meio de cujas unidades, com as categorias que convierem, tendo-se em vista manter em satisfatório e normal funcionamento a rêde nacional dai decorrente, fiquem estabelecidas as necessárias comunicaçōes intermunicipais de cada Consórcio, e dêstes entre si e com as Capitais estaduais funcionando o sistema suplementar, a cargo e principalmente para os fins das Agências do Instituto Brasileiro de Estatistica, mas facultado támbém o seu uso aos Consórcios Intermunicipais e aos Municípios, para as comunicações urgentes das respectivas administrações;

e) um serviço semanal, ou no mínimo mensal, de comunicações aéreas, por meio de helicópteros leves; ficando o empreendimento a cargo, também, do Instituto Brasileiro de Estatística, para os fins dos serviços próprios ou em regime de cooperação, mas destinado a atender igualmente, em caso de urgência, às administrações municipais ou intermunicipais, ou ao próprio Estado e à União Federal;

f) uma Unidade de Fôrça Pública Estadual à qual incumba distribuir por todos os Municípios e Distritos dos Consórcios, em condições de re- 
nová-los ou reforçá-los prontamente, os contingentes policiais necessários à efetiva segurança das pessoas e da propriedade;

g) uma Linha de Tiro, do Exército Nacional, em cujas fileiras se possa efetuar o treinamento militar dos conscritos mas sem deslocá-los do ambiente social em que vivam;

h) um Hospital Geral em cada uma das Capitais de Consćrcio, e a rêde de pequenos hospitais ou Postos de Saúde, adequadamente planejados e organizados de modo que fiquem satisfatòriamente servidas, no que tange à proteção contra doenças e acidentes, tôdas as populações - tanto urbanas como rurais - do Consórcio;

i) no mínimo, uma rêde de estabelecimentos de ensino médio ou superior, conforme o caso, sediados na Capital de cada Consórcio, e em condições de prover preferencialmente aos seguintes ramos didáticos: ensino secundário, ensino normal ou magisterial, primário, ensino comercial, ensino técnico-industrial, ensino de serviço social, ensino de odontologia, farmácia e enfermagem (geral e obstétrica) e ensino básico de organização e direção de emprêsas (de serviço público ou privadas);

j) em cada sede municipal, um curso primário, em cada sede de Consórcio, um curso médio, para o ensino das técnicas essenciais do artesanato e prestação de serviços coletivos ou pessoais segundo as, exigências atuais da organização social brasileira;

k) uma rêde de hotéis que deixe bem servidas, nesse particular, e em condições adequadas, não só a sede do Consórcio mas também suas demais cidades.

l) pelo menos em cada Municipio ou Subterritório, um Centro Agropecuário, de assistência e fomento à agricultura, à pecuária e às indústrias rurais e que possuam ou mantenham:

\section{1. uma Seção de Serviço Social Rural;}

2. uma Colônia-Escola, para formação profissional e socialização não só dos elementos levados pelos serviços de Imigração e Colonização, mas tämbém de famílias ou individuos marginais que vivam miseràvelmente na circunscrição e precisem ser recuperados, em condições satisfatórias de saúde, educação e capacidade, para o trabalho e a vida rural;

3. uma escola de ensino elementar - geral e especializado - de Agricultura, Zootécnica e Indústrias Rurais, mas que disponha também de uma seção de internato segundo o modêlo do Instituto João Pinheiro, de Belo Horizonte, destinada a menores desamparados ou desajustados fami liares;

4. um serviço ambulante de «semanas de educação e assistência ruralista», mediante acôrdos em conjunto com o Ministério da Agricultura e as Secretarias de Agricultura dos Estados, a que se possam juntar entidades privadas para tanto qualificadas;

5. um consultório dispensário popular, para assistência e orientação gratuita aos pequenos agricultores, criadores, industriais ou artesãos rurais e também para a distribuição gratuita ou a crédito, conforme o caso, dos im. 
plementos de trabalho e os mais indispensáveis utensilios domésticos, às familias de mais baixo nível econômico;

6. armazéns, silos̀ e aparelhagem frigorifica, que permitam oferecer às pequenas atividades rurais de cada municipio, não só os benefícios do armazenato e conservação a baixo custo, dos produtos agrícolas, mas também - recurso da «warrantagem» à base de preços mínimos compensadores, prèviamente fixados;

m) uma rêde unificada de exatorias fiscais, organizada modelarmente e sob forma convencional, a serviço comum da União, dos Estados e dos Municipios;

n) uma inspetora, com as Subinspetorias necessárias, do Instituto de Imigração e Colonização;

o) uma rêde escolar primária em condições de atrair, socializar, instruir, educar - física, intelectual, artística e moralmente, assegurando-lhes ainda a prática das garantias, facilidades, comportamentos, oragnizações e técnicas essenciais para a vida individual e para a conveniência familiar, social e civica - todos os infantes e jovens de um e outro sexo compreendidos na população em idade escolar dos municipios unidos; mas estabelecida, complementarmente, a organização dos Clubes Agrícolas Escolares e dos Clubes de Trabalho;

p) pelo menos um pôsto meteorológico em cada sede dos Consórcios;

q) uma rêde de organizações cooperativistas, abrangentes de todos os Municipios;

r) a organização do crédito agrícola estendida a todo o Consórcio;

s) a rêde de Associações Rurais Municipais mas a cada uma delas facilitado, medante adequados auxílios, o contrato de um Agrônomo, como Secretário-Assessor;

t) uma organização esportiva, que interesse a todos os Disetritos;

u) um aparelhamento contra incêndio, para proteção, pelo menos, da sede do Consórcio;

v) a instituição de modesta «Santa Casa de Misericórdia» em cada cidade que ainda não possuir hospitais;

$x)$ a organização, ainda que rudimentar em comêço, dos arquivos, musẹu e bibliotecas municipais, em tôdas as c dades;

y) a organização de uma Banda Municipal e de um centro de cultura artística em cada cidade.

$\S 2 .^{\circ}$ Fixadas as iniciativas a serem tomadas pelos Conselhos Administrativos dos Consórcios, serão solicitadas a colaborar nas respectivas campanhas, formulando os esquemas e planos convenientes, e lançando a publicidade necessárias, tôdas as organizações públicas e privadas, nacionais, regionais, ou locais, para tanto qualificadas, e especialmente a Associação Brasileira de Municipios, o Instituto Brasileiro de Administração Municipal, o Instituto Brasileiro de Estatística, o Departamento Nacional de Geografia, as Confederações Nacionais da Agricultura, da Indústria e do Comércio, a Fundação Getúlio Vargas, a Associação Brasileira de Educação, a Liga da Defesa Nacional, o Instituto de Colonização Nacional e o Instituto Brasileiro de Ciência, Educação e Cultura. 


\section{CAPÍTULO IV}

\section{Do Circunscricionamento Municipal}

Art. 35. São fundamentais para a normalidade política, social e econômica da vida da Federação, a disciplina e o condicionamento básico, de âmbito nacional, para o circunscricionamento territorial - judiciârio-administrativo - da República.

$\S 1 .^{\circ}$ Sem embargo da autonomia dos Municipios, êsse circunscricionamento é desdobrável por atos legislativos que estão compreendidos na competência implícita dos Estados, exercida essa competência, porém, dentro das normas e critérios gerais que forem fixados pelo Poder Legislativo Federal, conformemente ao disposto nos $\S \S 10^{\circ}$ e $2 .^{\circ}$ do art. 33 desta Lei.

$\S 2 .^{\circ}$ O disciplinamento de base do quadro circunscricional da República é feito a titulo de emergência no presente diploma legal, até que se elabore a respectiva Lei Orgânica, tendo tais normas como fundamento o disposto na Constituição, art. 65 alinea VIII, onde é reconhecida a competência da União em matéria de «limites territoriais», combinadamente com o art. 66, I, pelo qual se disciplina a matéria referente aos limites exteriores, reconhecidos por «acôrdos nternacionais» e cuja definição resultara de convenções ou tratados, aprovados pelo Poder Legislativo Federal jara «legislar» sôbre assuntos de interêsse nacional que têm reconhecidamente por fundamento a «divisão territorial», bem assim, em geral, "sôbre tôdas as matérias da competência da União» (Art. 65, inciso IX).

$\S 3 .^{\circ}$ A medida a que se refere o presente artigo é considerada urgente, não só para salvaguarda efetiva do instituto constitucional que é a «autonomia municipal», até agora sem sentido realista como igualmente para asseguar eficácia financeira e relativa eqüidade ao rateio da cota do Impôsto sôbre a Renda. Tal cota é atribuída aos Municípios em condições iguais, mas, por isso mesmo, deverá ser distribuída entre unidades que de alguma sorte se possam equivaler, e constituidas sob determinado critério, a fim de que não se contravenha ao mesmo princípio de eqüidade que está no espirito do texto constitucional (art. $15, \S 4 .^{\circ}$ ).

Art. 36. Até a promulgação da lei orgânica federal a que se refere - $\S 10^{\circ}$ do artigo precedente, terão vigência plena, conjugadas com as disposições especiais da presente Lei, as normas e os critérios que foram estabelecidos uniformemente para todo o país na Convenção Intergovernamental de Estatística (Cláusulas 14. ${ }^{\mathrm{a}}$ e $15 \mathrm{.}^{\mathrm{a}}$ ), celebrada em 1936, e tiveram a sistemática legislativo-regulamentar constante do Decreto $n$. $^{\circ} 311$, de 2 de março de 1938, com a alteração do Decreto-lei n. ${ }^{\circ} 522$, de 28 de junho de 1938.

Art. 37. Em aditamento às normas referidas no art. 36 , a reordenação dos quadros judic ário-administrativos estaduais e territoriais se processará na conformidade das categorias e dos limites da área fixados nos parágrafos seguintes:

$\S 10^{\circ}$ Entre as unidades fundamentais de circunscricionamento para fins administrativos, mas na dependência dos atos legislativos ou convencionais que lhes efetivem a criação, ficam previstos, além dos Consórcios, 
a serem instituídos mediante acôrdo multilateral entre os Municípios, conforme o disposto no Capítulo II desta Lei, os Territórios Estaduais e os Territórios Municipais, bem assim a categoria de Subterritórios, êstes como subdivisão dos Territórios Estaduais ou Federais.

$\S 2 .^{\circ}$ Nenhum Municipio já criado ou que venha a ser criado abrangerá mais de $2.500 \mathrm{~km} 2$, considerada esta a área limite para que seja pràticamente possivel e se torne eficaz a ação do Govêrno sôbre todo o território jurisdicionado, a exprimir ùtilmente as diferentes formas do exercício real e necessário da soberania nacional.

§ 3. Por ato de criação ou em virtude de desmembramento efetuado ulteriormente à presente Lei, não se erigirá Município com área inferior a $500 \mathrm{~km} 2$. Será essa a área mínima admissivel para assegurar a potencialiulteriormente à presente Le , não se erigirá Municipio com área inferior a organização municipal, de maneira a ficar assegurado, em pleno, o alto papel só:io-econômico e político que, sob formais garantias constitucionais, aos Municípios cabe desempenhar.

$\S 4 .^{\circ}$ Quando o território mencionado exceder o limite estabelecido no $\S 2 .^{\circ}$ e não possuir condições para a criação de novos Municipios, que possam participar desde logo da efetiva organização consorcial, serão as áreas excedentes destacadas, por lei estadual ou federal, conforme o caso, dos Municípios a que pertencerem. Ficarão fazendo parte das reservas geográficas sujeitas a imediato esfôrço colonizador por parte do Poder Estatal, e para êsse fim serão submetidas ao estatuto de «Territór os» - Municipais ou Federais.

§ 5. O «Território Municipal» ficará incluido em Consórcio Municipal já organizado; terá superfície geográfica compreendida entre 500 e $2.500 \mathrm{~km} 2$. O «Território Estadual» compreenderá a área reservada a um ou mais de um Consórcio Municipal, desde que a extensão geográfica seja contínua e superior a 50.000 mas inferior a $250.000 \mathrm{~km} 2$. O «Território Federal», que não será inferior a 250.000 , nem superior a $550.000 \mathrm{~km} 2$, se dividira em Consórcios Municipais também (já organizados ou a organizar), cada um dos quais, porém, não terá menos de 10.000 nem ma s de $50.000 \mathrm{~km} 2$.

$\S 6 .^{\circ}$ Os Consórcios Municipais ainda «em ser», que forem subdivisões do Território Estadual ou Federal, constituirão subterritórios; cada um dos quais não terá igualmente menos de 10.000 nem mais de $50.000 \mathrm{~km} 2$ e po:suirá a respectiva administração subterritorial.

$\S 7 .^{\circ}$ Cada Distrito judiciário-administrativo municipal, territor al ou subťerriteorial jurisdicionará área não superior a $500 \mathrm{~km} 2$ (correspondente a um círculo de doze quilômetros de raio), limite êsse de que decorrerá o distanciamento médio em condições de permitir a presença efetiva, para os fins da conveniência social e cívica, de assistência e proteção ao povo, do Poder Público, em tôda a área jurisdicionada.

$\S 8 .^{\circ}$ A parte do espaço geográfico reservado a qualquer Consórcio que, em virtude do disposto no $\S 1 .^{\circ}$. fica excluida dos atuais Municipios, que os constituirem e onde ainda não seja possivel criar novas unidades 
municipais, formará um ou mais de um Território Municipal, cujo povoamento e organização ficarão entregues aos próprios Municipios Unidos.

§ 9. Quando na área de um Consórc o «ém ser» não existirem pelo menos cinco unidades municipais organizadas com os requisitos legais, êsse espaço geográfico será colocado provisòriamente na condição de Território Estadual, cabendo à respectiva administração, com as vantagens facilitadas por esta Lei, tôdas as iniciativas e responsabilidades atribuídas às Uniões Municipais.

§ 10. Também as glebas ainda não municipalizáveis e que, por isso mesmo, houverem de ser destacadas dos atuais Municipios para se distribuirem na forma prevista nesta Lei entre Consórcios inteiramente «em ser» ou que ainda incluam Territórios Municipais, e assim sejam transformáveis em Territórios Estaduais ou federais conforme a extensão territorial abrangida ( $\S 50^{\circ}$ dêste artigo), serão consideradas as grandes unidades geográficas ainda em processo de colonização intensiva. Quando a tarefa colonizadora ficar a cargo do Estado, tratando-se de Território Estadual, será tal encargo, todavia, exercido em ação conjunta com a União, agindo esta por intermédio do Instituto Nacional de Imigração e Colonização, na forma que fôr convencionada.

$\S 11$. Incumbe ao Conselho Nacional de Geografia assinalar, para os devidos fins, as áreas contínuas em condições de constituirem os Territórios Mun cipais, Estaduais ou Federais, em conformidade com os critérios assentados nesta Lei.

$\S$ 12. Tanto nos Territórios Federais como nos Territórios Estaduais, serão efetivados os Consórcios Municipais previstos para o seu âmbito geográfico, à medida que, com a criação de novos Municipios, fiquem satisfeitas as condições estabelecidas nesta Lei.

Nesse caso, será, de imediato, suprimida a administração subterritorial, substituindo-se a esta a administração dos Municípios Unidos.

$\S$ 13. As administrações dos Territórios Estaduais, ou dos Subterritórios, federais ou estaduais, nas áreas correspondentes a futuros Consórcios, exercerão intensivamente as finalidades promotivas reservadas nesta Lei aos Ccnsórcios, até que se possam êstes organizar com apoio na autonomia municipal.

$\S 14$. Os Territórios Municipais serão administrados "in solidum» pelos Municípios do Consórcio, por intermédio dos órgãos executivos dêste, mas com auxílios especiais adequados, tanto do Estado, quanto da União, os quais serão estabelecidos em comum.

$\S$ 15. A administração dos Territórios Municipais, e dos Subterritórios Federais e Estaduais, terá em vista primordialmente o povoamento e a organização sócio-econômica das áreas rurais ainda não efetivamente cobertas pelo «quadro municipal», ao qual os Consórcios vão fortalecer, equilikrar e consolidar. Essa administração pioneira terá por instrumento a 
imediata instalação, em cada um dêles, de um Centro Agropecuário, que manterá, anexa, uma Colônia-Escola.

$\S$ 16. Os Consórcios Municipais, bem como os Subterritórios ou Territórios, poderão, mediante contrato ou Convênio, entregar a organização dos Centros Agropecuários e Colônias-Escola a que se refere o parágrafo precedente, ao Instituto de Colonização Nacional, como órgão já reconhecido de utilidades públicas.

$\S 17$. As áreas resíduas da divisão municipal dentro de um Território ou Subterritório, onde ainda não se possa organizar o Consórcio Municipal, com os respectivos «Territórios Municipais» se fôr o caso, serão distribuidas por tantos Distritos coloniais (sediados em Fazendas-Modêlo) quantos se puderem formar sob a condição de não abranger nenhum dêles área superior a $500 \mathrm{~km} 2$.

$\S 18$. Por fôrça dos acôrdos previstos nesta lei para os fins de abertura e organização dos Centros Agropecuários que se destinam a funcionar ccmo núcleos-políticos do povoamento e organização sócio-econômica, poderão ser empregadas, na forma que for convencionada unidades militadas ou policiais para êsse fim especialmente organizadas e equipadas.

§ 19. Ao Centro Agropecuário, como organização nuclear do Território Municipal ou de Subterritório, é que caberá organizar e inanter as Fazendas-Modêlo que forem sedes dos respectivos Distritos Coloniais. Funcionará tal estabelecimento rural como agência de povoamento e rudimentar «Colônia-Escola» (ou escola prática, em curto estágio, para colonos avulsos ou famílias de colonos). Serão seus internados todos quantos - imigrantes, adventicios, ou elementos da população já existente - se destinarem à condição de trabalhadores rurais ou pequenos sitiantes no território do Distrito. Aos ex-internados das Fazendas-Modêlo, bem como aos agricultores de maior tirocinio, preparados nas Colônias-Escola em mais longo estágio, se garantirá a ulterior aquisição de terra própria, com a ajuda ıecessária para sua proveitosa exploração, mas sempre que possivel sob organização cuoperativista.

$\S 20$. Nos Centros Agropecuár os e Fazendas-Modêlo dos Territórios Municipais ou dos Subterritórios se sediarão, com a descentralizaçăo distrital necessária, todos os órgãos e serviços ex gidos pela vida civil da incipiente comunidade formada pelos primeiros povoadores das áreas desabitadas.

§ 21. Cada qual dos Territórios e Subterritórios federais ou estaduais, como «áreas coloniais» (áreas a nda desertas ou subdesenvolvidas), organizadas na conformidade do disposto nos parágrafos precedentes, terá uma sede ou "capital» - territorial ou subterritorial - tantas sedes municipais (cidades) e distr tais (vilas) quantas necessárias a fim de poderem funcionar de forma efetiva e não apenas nominal, em relação às áreas das respectivas circunscrições, erigidas dentro dos limites de espaço fixados nesta Lei, coma organizações nucleares eficientemente operantes para objetivos de povoamento, proteção aos silvícolas se fôr o caso, defesa do solo flora e fauna, e organização rural, no seu tríplice sentido - social, econômico e politico. 


\section{CAPÍTULO $\mathrm{V}$}

\section{Dos Levantamentos Geográficos, Cadastrais e Estatistico-Censitários Municipais}

Art. 38. Como parte integrante du plano traçado na presente Lei, e visando à mobilização dos recursos e energias nacionais para efetivamente assistir e reerguer a vida municipal da Federação, particularmente no que respeita às populações rurais, ficam específica e correlateamente ampliados os encargos de natureza municipal do Conselho Nacional de Estatistica. Para êsse fim, os objet vos do C.N.E., que são considerados de primeira necessidade e da competência concorrente da União, dos Estados e dos Municipios, pertinentes aos cadastros, registros e levantamentos munic pais, serão dirigidos também, d retamente, a cada um dos Distritos Rurais da República, como tais considerados os que não forem sedes de Município.

$\S 1 .^{\circ}$ Ficam autorizados os Convênios especiais que tiverem por objeto delegar ao Inst tuto Brasileiro de Estatística, garantidos os direitos adquiridos dos respectivos serventuários bem assim sem ônus para o Estado quer quanto ao pessoal quer quanto ao material, os encargos referentes ao «Registro Civil» dos Distritos Rurais, o qual será executado pelas Agências Distrita s de Estatística. Tais Agências terão concomitantemente a incumbência de organizar e manter atualizado o Cadastro dos Estabeiecimentos Rurais existentes na totalidade dos mesmos Distritos e, ainda, nos «quadros rurais» dos distrtos das cidades. Será permitida a delegação aqui prevista, também com referência aos Distritos urbanos, quando os Estados nisto convierem no intuito de assegurar a perfeita regularidade do instituto do Reg stro Civil em todo seu território.

§ 2..$^{\circ}$ Do «auxílio» do Govêrno Federal ao Instituto Brasileiro de Estatística, previsto na cláusula $1 .^{a}$, inciso XVII, alinea «i» da Convenção Intergovernamental de 11 de agôsto de 1936, a presente Lei assegurará o volume e o incremento adequados para que possa cobrir o custeio, sem colapsos, da totalidade dos serv ços e atividades que competirem ao I. B. G. E. por delegação solidária da União, dos Estados e dos Municipios.

§ 3. Tal obrigação fica nestes precisos têrmos assumida pela União. a titulo de concurso financeiro especial, para os fins de atividades técricoadministrativas que são da competência concorrente das três órbitas de Govêrno, mas cuja eficiência e compreensão nacional, uma vez obtidas da fórmula convencional, permanecem, entretanto, como de preponderante e essencial interêsse para a Federação em conjunto.

$\S 4 .^{\circ}$ Em conseqüência, e a partir de 1958, depois de efetivado o disposto na presente Lei, os recursos orçamentários dos Estados e dos Ministérios Federa's ficarão totalmente desobrigados dos encargos financeiros atuais, referentes à Estatística Geral nos respectivos âmbitos da jurisdição. Apenas continuarão sob a responsabilidade adminisetrativa e financeira direta da União, dos Estados e Territórios, os serviços especializados que exclusiva ou completamente forem incumbidos de levantamentos estatísticos considerados in ternos ou de interêsse imediato para os órgãos das respectivas administrações 
a que ficarem tais serviços atribuidos, devendo os seus resultados, sem embargo, considerar-se subs diários das operações estatísticas gerais.

$\S 5 .^{\circ}$ Serão, outrossim, liberados, a partir também de 1958 , os recursos com que os Governos Municipais vêm financiando as coletas de estatistica municipal em virtude dos Convênios realizados - nos têrmos do Decreto-lei n. 4.181 ; de 16 de março de 1942 .

$\S 60^{\circ}$ O Conselho Nacional de Estatística constituirá, para isso utilizando os mesmos recursos orçamentários de que dispuser anualmente, as reservas gera's ou especiais necessárias ao aprofundamento ou à extensão das pesquisas de Estatística Geral em virtude de eventuais exigências da administração pública, bem como à ampliação da rêde de coleta estatística para atender às novas circunscrições que forem sendo criadas, e, quanto possivel, a nda à própria realização dos Recenseamentos Gerais da' República.

§ 7. A ser incluido no orçamento que vigorará para 1957, fica criado o adicional de três por cento $(3 \%)$ ao importe global do que fôr cobrável de cada contribuinte (pessoa física ou jurídica) do Impôsto sôbre a Renda, a começar do referido exercício. A arrecadação dêsse ad cional será contabilizada à parte, para que ao importe da receita de um exercício corresponda a rubrica do «auxílio» ao Instituto no Orçamento Geral da República para o exercício imediato, na conformidade do disposto no $\S 2^{\circ}$ do art. 38 da presente Lei.

$\S 8 .^{\circ}$ As importâncias do auxilio a que se refere o parágrafo anterior serão entregues pelo Tesouro Nacional ao Instituto Brasileiro de Estatística, por intermédo do Banco do Brasil. Êsse pagamento se fará cm quatro parcelas anuais, na primeira quinzena de cada trimestre, salvo determinação diferente do Pres dente da República para atender a representação fundamentada do Conselho Nacional de Estatística.

§ 9. Para os fins dêste artigo, o Instituto Brasileiro de Estatistica, à medida que se desdobrar o circunscricionamento judiciário-administrativo da República, manterá a competente rêde estendida a todo o territór o racional, com as articulações hierárquicas e meios de comunicação necessários, conforme o previsto na presente Lei. As Agências Distrita's constituirão os centros de trabalho para cobertura de todos os objetivos - civis ou militares - da administração pública, quer dos Municip os, Estados e União Federal, quer das entidades autárquicas e paraestatais, cujo atendimento depende de dados estatísticos, cadastrais e censitários pormenorizados, relativamente aos grupos demográf cos que se diferenciam na divisão judiciário-administrativa constituida pelos Distritos e Subdistritos.

Art. 39. Ao atual Conselho Nacional de Geografia e respectiva Secretaria-Geral, criados pelo Decreto n. ${ }^{0} 1.527$, de 24 de março de 1937, e que sòmente por ato unilateral da Un ão foram integrados no Sistema Estatístico Brasileiro, é restituída a plena autonomia em relação ao mencionado sistema.

$\S 10^{\circ}$ Custeados exclusivamente pela União, integrar-se-ão os referidos organismos no Min stério da Educação e Cultura, constituindo o Departa- 
mento Nacional de Geografia, em cuja estrutura se conservará a distinção entre o órgão técnico-deliberativo intergovernamental e o respectivo órgão executivo, a ambos mantida a final dade de cooperação, nos têrmos dos acôrdos que forem estabelecidos, mas sem prejuízo do caráter federal do referido Departamento.

$\S 2 .^{\circ}$ Entre as atribuições do Departamento Nacional de Geografia fica expressamente mantida a de organizar e rever, com a colaboração pos sivel dos Estados e dos Municípios, os mapas mun cipais do país, com a competente divisão distrital, na conformidade das leis qüinqüenais que efetuarem alterações no quadro território-administrativo e judiciário da $\mathrm{Re}$ pública.

$\S 3 .^{\circ}$ Para cumprimento do disposto neste artigo, o Poder Executivo baixará regulamento, onde serão consolidadas, dentre as disposições normativas do atual Conselho Nacional de Geografia, aquelas que forem extensivas ou especificamente referentes aos órgãos que passam a formar o Departamento Nacional de Geografia.

$\S 4 .^{\circ}$ O decreto a que alude o parágrafo precedente incorporará ao quadro dos servidores federais o pessoal do referido órgão.

$\S 5 .^{\circ}$ O mencionado Regulamento poderá incluir o Departamento $\mathrm{Na}$ cional de Geografia no sistema de órgãos técnico-científicos presidido pelo Conselho Nacional de Pesquisa; ou, ainda, incorporá-lo, como órgão diretamente cooperante nas atividades universitárias, à Universidade do Brasil.

$\S 60^{\circ}$ A opção admitida no $\S 50^{\circ}$ será tomada com objetivo de colocar - Departamento Nacional de Geografia na posição admin strativa que se verificar a mais favorável à plena expansão de suas finalidades, que serão ao mesmo tempo de pesquisa cientifica, de operação técnica e de atuação educativa e cultural, nos dominios dos estudos geográficos e formação, aperfeiçoamento e especialização dos quadros dos Geógrafos Brasileiros.

$\S 7 .^{\circ}$ Tôda coordenação que se verificar necessária, das atividades do Departamento Nácional de Geografia com o Instituto Bras leiro de Estatística, bem assim com quaisquer outros órgãos administrativos, didáticos, técnicos ou científicos cujos serviços devam articular-se com os de natureza geográfica, será efetuada por meio de acôrdos ou convênios bilaterais os quais, quando fôr o caso, serão precedidos de autorização legal dos governos co-interessados.

$\S 8 .^{\circ}$ O Poder Executivo proporá ao Congresso projeto de lei com as d'sposições especiais julgadas necessárias ao aperfeiçoamento e intensificação das atividades do Departamento Nacional de Geografia.

Art. 40. O atual sistema intergovernamental dos serviços de Estatística, restabelec da a originária estrutura e competência, passará à denominação de Instituto Brasileiro de Estatística que sucederá ao Instituto Nacional de Estatística, a sob essa denominação Geográfica e Estatística (anteriormente, Instituto Nacional de Estatística), como entidade de Dire to Público instituída e supervisionada pelas três órbitas governativas da Federação. A entidade permanecerá diretamente subordinada à autoridade nacional do Presidente da República consoante o estabelecido na Convenção óacional de 
Estatística em conseqüência do caráter intergovernamental que, no dominio exclusivo da Estatística, the foi contratualmente outorgado sob autorização e ratificação legal.

$\S 1^{\circ}$ A Convenção Nacional de Estatística é mantida em tôdas as suas conseqüências jurídicas técnicas e adminisetrativas, enquanto não acordarem o contrário a União e a maioria absoluta dos Estados.

§ 2. ${ }^{\circ}$ Seus dispositivos completados pela legislação conseqüente ficam considerados como «disposições orgânicas», «disposições gerais» ou «disposições especiais», conforme a natureza dos assuntos versados, salvo as que caírem em caducidade por fôrça das novas cláusulas convencionais autorizadas na presente Lei.

Art. 41. O Instituto Brasileiro de Estatística (I.B.E.) realizará os objetivos fixados:

a) na Convenção Nacional de Estatistica - estatuto elaborado e promulgado na vigência da Constituição de 1934 e conformemente aos princípios de cooperação intergovernamental que essa Carta Política aprovou e foram firmados em 11 de agôsto de 1936 entre o Govêrno da União e a unanimidade dos Governos das Unidades Federadas, também representando êstes «in solidum» os respectivos Municipios, e sob a ratificação imediata por tôdas as Altas Partes contratantes;

b) nos Convênios Nacionais de Estatística Mun cipal celebrados completamente sob as competentes autorizações e ratificações legais entre de um lado, a União, os Estados, os Territórios e o Distrito Federal, e, de outro lado, a totalidade dos respectivos Municipios, com a cláusula de automática extensão aos novos Municipios que viessem a ser criados; tendo tais Convênios por objeto assegurar a eficiência dos levantamentos comunais que devem servir de base às estatísticas brasileiras, tanto federais como estaduais e municipais, e à organização de segurança nacional;

c) em a nova Regulamentação do Conselho Nacional de Estatística, no que decorrer da presente lei e em revisão ao Decreto $n .^{\circ} 1.200$, de 17 de novembro de 1936, devendo o mesmo Conselho projetar essa regulamentação, na qualidade de órgão intergovernamental que lhe advém da Convenção $\mathrm{Na}$ cional de Estatística e na conformidade do Decreto Legislativo n. ${ }^{\circ} 24.609$. de 6 de julho de 1934, aprovado pela Constituição de 1934 .

Parágrafo único. O regulamento previsto na alinea c dêste artigo será aprovado e decretado pelo Presidente da República, mas na estrita conformidade dos compromissos assumidos em comum pela União e pelos Estados.

Art. 42. O Instituto tem sede na Capital da República, sendo o seu fôro o da União Federal.

$\S 10^{\circ}$ O Instituto gozará dos privilégios e prerrogativas da Fazenda Pública federal, estadual e municipal.

$\S 2 .^{\circ}$ As importâncias das multas impostas pelo Conselho Bras leiro de Estatística na forma da respectiva legislação, constituem renda extraordinária do Instituto. A arrecadação será feita na forma do Regulamento que fôr baixado pelo Poder Executivo dentro do prazo de noventa (90) dias as condições estabelecidas nesta Lei. 
Art. 43. A supervisão e representação do Instituto bem como a Presidência do Conselho Nacional de Estatística como órgão efetivamente dirigente do Sistema Estatístico Brasileiro, serão exercidas - na forma prev sta pelas leis e disposições consubstanciadas na Convenção Nacional de Estatística - por um Presidente livremente escolhido pelo Presidente da República entre os brasileiros natos que se distinguirem por notável saber e notória experiência no trato da co sa pública. A direção do Instituto se pautará pelas Resoluções do Colégio Governativo do aludido Conselho (art. $46, \S 1 .^{\circ}$, alinea a).

$\S 10^{\circ}$ O Presidente do Instituto, com a aprovação da Junta Executiva do Conselho, nomeará, o Secretário-Geral, cuja escolha atenda aos requisitos do art. 44 desta Lei.

$\S 20^{\circ}$ O Séretário-Geral do I.N.E. exercerá a adm nistração geral da entidade, segundo a orientação da Presidência e as "Resoluções» normativas ou deliberativas do Colégio Governativo do Conselho Nacional de Estatistica, levando também em conta as proposições do Colégio Consult vo do mesmo Conselho.

Art. 44. A direção ou chefia dos órgãos técnicos e publicitários de Estatística, integrantes do Instituto, sòmente será exercida por servidor do Sistema Estatístico Brasileiro, por professor de Estatística admitido mediante concurso, por diplomado em curso superior de Estatística, ou por técnico de reconhecida competência profissional em Estatistica, comprovada no exercício de cargos que impliquem a responsabilidade dessa espec alização.

Art. 45. Fica o Govêrno autorizado a firmar pela União Federal com as Unidades Federadas, em decorrência da legislação reguladora da Convenção Nacional de Estatística, um «Protocolo Adicional de finalidade complementar e interpretativa à sobradita Convenção».

$\S 10^{\circ}$ O mencionado Protocolo assentará ou consolidará:

a) as normas que exprirem as deliberações, em comum. dos Governos compactuantes, e que se destinarem ao novo Regulamento a ser baixado pelo Govêrno Federal a fim de que, ao órgão colegial intergovernativo previsto na Convenção Nacional de Estatística, conforme o autorizado no art. 41, alinea 《c» desta Lei, fiquem aplicadas orgânicamente as autorizações legais em vigor, as quais terão como objet vo unificar a direção e administração do Sistema Estatístico Brasileiro;

b) as medidas executivas para que, na forma legal estabelecida, e como delegação administrativa, se transfiram à gestão do Conselho e portanto em condições idênticas para todo o país, as atividades dos atua s «órgãos centrais» do Sistema, tanto os federais como os estaduais, acompanhadamente do respectivo material de consumo, equipamento e documentação, conforme o previsto no $\S 3 .^{\circ}$ do art. 38 ;

c) complementarmente ao previsto na alínea precedente, as medidas de efetiva articulação entre os diferente órgãos espec alizados de Estatística (federais e estaduais), de um lado, e, de outro lado, os órgãos de levantamento, coleta, elaboração e divulgação sob a responsabilidade direta do I.B.E.; 
d) similarmente ao previsto nesta Lei quanto aos «órgãos centrais federais», a forma de aproveitamento do pessoal dos Estados do Distrito Federal e dos Territórios, pertencentes às repartições transferidas nos quadros e tabelas do Instituto, assegurados todos os direitos vigentes na data, sem prejuízo, todavia, dos servidores já classificados no quadro privaet vo da ent dade;

e) as obrigações do Instituto para com os Governos Estaduais, do Distrito Federal e dos Territórios quanto ao fornecimento obrigatório regular e atual, e com tôda a prioridade possivel, das estatisticas, informações, publicações e estudos que forem julgados ndispensáveis à vida administrativa e econômica das Únidades da Federação, semelhantemente ao estabelecido com referências aos órgãos ministeriais de Estatística Geral;

f) a participação dos Estados e Territórios na direção unificada e na fiscalização do Instituto Brasileiro de Estatística, por intermédio do Colégio Governativo do Conselho Nacional de Estatistica composto, tal Colégio, de delegados oficiais especialmente credenciados, os quais serão escolhidos entre os membros dos respectivos Governos, e designados por decreto executivo;

g) os critérios segundo os quais, dentre os servidores que colaborarem nas at vidades do Instituto, se caracterizem os que, a titulo efetivo e privativamente, ficarem integrados no quadro da entidade para os efeitos do disposto na presente Lei.

$\S 2 .^{\circ} \mathrm{O}$ «Protocolo Adicional» previsto neste artigo será submetido imediatamente à aprovação por decreto executivo, dos Governos participantes da Assembléia Convencional.

Art. 46. Efetuadas as transferências previstas no artigo precedente, os titulares da Junta Executiva Central do Conselho Nacional de Estatistica, excetuados os representantes militares e o do Ministério do Exterior, passam a ficar subordinados diretamente ao referido Conselho, como diretores dos seus «órgãos centrais», mas privados do caráter de representantes governa mentais.

$\S 10^{\circ}$ Conseqüentemente, e a partir da ratificação do «Prosocolo Ad cional», à Convenção Nacional de 1936, o Conselho Nacional de Estatistica sob a presidência do Presidente do Instituto compreenderá:

a) um órgão deliberativo intergovernamental - o Colégio Governativo do Instituto - que deliberará por meio de «Resoluções» aprovadas pela maioria absoluta de suas duas bancadas, a saber, a «Delegação Federal» (um representante para cada Ministério e cada Território) e as «Delegações Regiona s» (um representante - Secretário de Estado do respectivo Govêrno - para cada uma das Unidades da Federação, na forma da alinea «f» do $\$ 10^{\circ}$ do art. 45 desta Lei);

b) a Junta Executiva Central, composta do Secretário-Geral do Inst tuto e dos Diretores dos órgãos Centrais da União, do Distrito Federal e do Estado do Rio de Janeiro, e ainda dos membros do Conselho que forem representantes dos Ministérios Militares e do Ministério do Exterior, como órgão auxiliar da administração do Conselho, à qual caberá assistir ao Presidente na interpretação, aplicação e suplementação das Resoluçŏes do Colégio Governativo; 
e) um Colégio Consultivo, que se reunirá uma vez cada ano e deliberará por meio de "proposições», cabendo assento nessa assembléia. com d reito de voto, em igualdade de condições ao Secretário-Geral do Instituto, aos assessôres técnicos designados pelos Delegados Governamentais ao Colégio Governativo, aos Diretores de Serviços e Departamentos autônomos diretamente dependentes do Conselho, aos Chefes de órgãos especializados de Estatística (federais, estadua s ou municipais), membros natos do Instituto ou a êle filiados, aos titulares em exercício dos Corpos de Consultores Técnicos e Comissões Especiais chamados a colaborar com o mesmo Conselho, e ainda os representantes das instituições culturais (aqui incluídos o Laboratório de Estatística, a Sociedade Brasileira de Estatística e a Escola Nacional de Ciências Estatisticas), cujas at vidades contribuam para o desenvolvimento da Estatística.

$\S 2 .^{\circ}$ Ao Colégio Governat vo do Instituto caberá:

a) a fixação do orçamento e o contrôle financeiro, convencional e administrativo do Instituto, mas sem prejuizo do disposto no art. 62;

b) assegurar a fiel execução dos princípios e do regime cooperat vo firmados na Convenção Nacional de Estatística e nas disposições legais federais, estaduais e municipais - aplicáveis à Entidade.

Art. 47. À segunda Assembléia Convencional de Estatística também é reconhecida a competência para assentar, no projeto de regulamentação orgânica do I.B.E. a que se refere o art. 41 , alinea «c» e seu parágrafo, a sistemat zação técnico-administrativa - estrutural e funcional da Entidade, de acôrdo com as seguintes normas fundamentais:

a) os órgãos executivos do Instituto formarão um único sistema «nacional» porém geogràficamente descentralizado, não só em relação aos Estados mas também quanto aos Municipios e aos Distritos;

b) o Sistema Estatístico Brasileiro terá unidade de direção superior - administrativa e técnica - quanto aos serviços própr os (privativos ou delegados); e unidade de direção técnica; apenas, quanto aos serviços filiados em virtude de lei ou de contratos bilaterais;

c) o enquadramento do Sistema Estatístico Brasileiro obedecerá a critérios de diferenciação orgânica, que lhe assegurem o caráter nacional, atendam à situação paritária reconhecida à União e aos Estados em matéria de Estatística, e assegurem às estatísticas brasileiras, cuja matéria o comporte, não só a discrim nação municipal, mas também a subdiscriminação distrital ou, mesmo, subdistrital.

Art. 48. A regulamentação geral do I.B.E. levará em consideração a seguinte estrutura fundamental, abrangente dos órgãos diretamente subord nădos ao Conselho Nacional de Estatística:

1. A Secretaria-Geral (órgão auxiliar do Conselho e destinado aos. fins de coordenação geral - administrativa, técnica e cultural - entre os. órgãos do Instituto), com o qual ficam articulados ou dirigidos diretamente pela Entidade, na forma compativel com a situação peculiar a cada qual.

2. O Laboratório de Estatística (órgão de planejamento, investigação e interpretação técnico-social, nos domínios da Estatíst ca). 
3. A Escola Brasileira de Estatística (órgão de cultura estatistica, elaboração cientifica e formação de profissionais no campo da Estatística), enquanto não fôr promovida pelo Ministério da Educação a sua incorporação à Universidade do Brasil, o que fica desde já autorizado.

4. Os Departamentos Ministeriais e Regionais de Estatística, como «repartições centrais» do Instituto para os trabalhos de coleta, critica, sistematização e elaboração.

5. As Oficinas Técnicas (tipográficas e mecânicas).

6. O Serviço de Transportes e Comunicações.

7. O Serviço Social.

Art. 49. O esquema dos órgãos filiados ao I.B.E. abrangerá os centros especializados de trabalho técnico ou c'entífico, nos domínios da Estatística, que já estiverem ou vierem a ser integrados em quaisquer, unidades administrativas:

1. da União Federal e dos Territórios Federais;

2. dos Estados;

3. das Entidades Paraestatais e de Economia Mista;

4. das Entıdades Autárquicas;

5. das Entidades ou Organizações privadas, estas, porém, mediante acôrdos bilaterais.

Art. 50. A Secretaria-Geral do Instituto compreenderá ou articulará conforme o caso:

I. A Assessoria (secretaria interna, técn ca e administrativa) do Conselho Nacional de Estatística;

II. Os órgãos de ação direta do Conselho:

1. O Departamento Geral Administrativo;

2. O Departamento Geral de Inquéritos e Levantamentos;

3. O Departamento Geral de Divulgação.

III. As «repartições centrais», incumbidas dos inquér tos, elaboração e documentação estatística:

1. Os Departamentos Técnicos Ministeriais (com designações e:pecíficas);

2. Os Departamentos Técnicos Estaduais e o do Distrito Federal (com o designativo da respectiva Unidade da Federação):

3. Os Departamentos Técnicos Territoriais (com o designativo do respectivo Território).

IV. Os órgãos de cadastro, prospecção, registro e investigação local (descentralizada), adequadamente conjugados com as «repartições centrais»;

1. As Inspetorias Regionais;

2. As Agências-Modêlo;

3. As Agências Municipais;

4. As Agências Distritais; 
5. As Agências Especiais;

Art. 51. Pela Secretaria-Geral do I. B. E. serão executadas, dirigidas ou coordenadas, conforme o caso, as atividades próprias (privativas ou delegadas) e as atividades filiadas de todos os centros de trabalho que integram o Instituto e se diferenciam como órgãos:

1. de administração;

2. de serviços auxiliares industriais (transportes, comunicações, conservação e artesanato, artes gráficas);

3. de verificação, seleção e elaboração;

4. de exposição, interpretação e divulgação;

5. de informação e consulta franqueada ao público;

6. de educação estatística e formação profissional;

7. de assistência econômica, social e cultural aos servidores do Irstituto.

Art. 52. São declaradas inalteráveis as disposições convencionais em vigor que vedem aos órgãos deliberantes do Sistema Estatístico Bras leiro adotarem Resoluções que contrariem, seja o voto da União, seja o voto dos Estados «in solidum», tomando êste último por maioria absoluta das delegações respectivas.

$\S 10^{\circ}$ Como princípio institucional básico do Sistema Estatistico Brasileiro é expressamente reconhecido que os interêsses nacionais, confiados. ao referido Sistema, ficariam inatingidos sem a solidar edade unânime que ora se verifica entre os Governos que o mantêm.

§. 2. Em conseqüência, a intenção de denunciar, seja o Convênio de Estatística Educacional de 1931, seja a Convenção Nacional de Estatística de 1936, bem como os Convênios padronizados de Estatística Municipal a que se refere o Decreto-lei $n .^{\circ} 5.981$, de 10 de novembro de 1943 , e ainda o Protocolo Adicional previsto na presente Lei, só será admissivel e se concretizará nas seguintes condições:

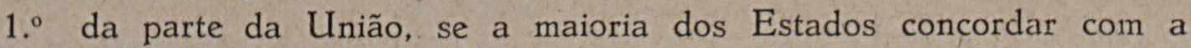
medida, preferentemente a providências corretivas da motivação da denúncia ficando aceito assim, por ambas as partes, explícita ou implìcitamente, o alvitre de se cancelar o Sistema que decorreu da aludida Convenção;

2. da parte de qualquer Estado, se com a denúncia e as suas conseqüências estiverem de acôrdo com a maioria dos Estados, uma vez se recuse o Poder Executivo Federal e admit $r$ o corretivo que o voto dos Estados indicar opcionalmente como alternativa para a caducidade do convencionado;

3. da parte de um Município, se, com essa atitude, em todos os seus efeitos regionais e nac onais, se solidarizar a maioria absoluta dos Municípios brasileiros, bem como a maioria dos Estados e a Unão ou, então, pelas referidas partes não fôr ace to o corretivo necessário para sanar o inconveniente, vício, rregularidade ou prejuizo invocado.

$\S 30^{\circ}$ Serão consideradas nulas de pleno direito, em face da Convenção Nacional de Estatística, as denúncias que já se houverem formulado ou noti- 
ficado, ou ainda quando se vierem a formular ou notificar, em desobediência ao principio de interêsse nacional solidário, que é regulado e preservado no parágrafo precedente sem prejuizo das sanções necessárias.

$\S 4^{\circ}$ Ficam, entretanto, reconhecidos tanto à União como aos Estados e aos Municipios os procedimentos judiciários - cujo fôro será o indicado no art. 42 - parte suspender ou corrigir atos dos órgãos dirigentes do Inst tuto que descumprirem as normas legais e convencionais pelas quais os mesmos se regem ou para embargar ou anular Resoluções ou atos dos órgãos deliberativos ou execut vos do Sistema que se contrapuserem às normas convencionais, desde que tais resoluções ou atos não forem suspensos por decreto motivado da Presidência da República, como decisão do processo, em grau de recurso, na sua fase administrat va.

Art. 53. Em decorrência da conceituação e finalidade da orçanização estatística brasileira (art. $10^{\circ}$ do Decreto Legislativo n. ${ }^{\circ} 24.609$, de 6 de julho de 1934), especialmente do disposto na segunda (alinea $c$ e g) da Convenção Nac onal de Estatística bem assim do compromisso constante do item $6 .^{\circ}$ do art. $8 .^{\circ}$ do Decreto Legislativo n. ${ }^{\circ} 946$, de 7 de julho de 1936 , é declarada a preeminência dos objetivos da União Federal no Sistema intergovernamental que dá suporte jurídico e legal ao Instituto que se continuará no I.B.E.

$\S 10^{\circ} \quad$ É reconhecido pela União Federal que dêsse estatuto jurid co the decorrem, com os referidos direitos de precedência, os correlatos deveres de assistência especial ao sistema, quando de outra forma os seus fins não puderem ser atingidos.

$\S 2 .^{\circ}$ Concordemente com o princíp o firmado neste artigo, o funcionalismo privativo da instituição fica equiparado ao funcionalismo federal para o efeito de aposentadoria, a qual será concedida pelo Govêrno na forma da Lei.

Art. 54. Na forma dos arts. $7 .^{\circ}$ e $8 .^{\circ}$ do Decreto Legislativo n. 24.609 , de 6 de julho de 1934, e mediante as condições de financiamento e as dispos ções convencionais referidas na presente Lei, é reconhecido que ao Instituto Brasileiro de Estatística - como entidade sucessora do Instituto Brasileiro de Estatistica e que permanece simultâneamente articulada às organizações administrat vas da União, dos Estados e dos Municípios - podem ser delegadas pelo Govêrno, pelas entidades de economia mista ou de direito privado, quaisquer atribuiçóes relacionadas com os levantamentos gerais ou espec ais de natureza estatistica.

Parágrafo único. Fica autorizada, para fins de realização unificada, em tudo que se refira a competências concorrentes e de finalidade comum, a transferência ao Conselho Nacional de Estatística, de tôdas as tarefas de planif cação, levantamento, critica, elaboração, exposição, divulgação, aná. lise e interpretação, das investigações e estudos referentes à Estatística (excluídos apenas desta autorização os de finalidade especializada ou estritamente administrativa) que ora se acham a cargo de repartições ministeriais, estaduais ou territoriais autônomas, dedicadas aos mesmos campos da Estatistica Geral, na qualidade de órgãos técnicos centra s nos respectivos sistemas administrativos. 
Art. 55. Por decreto executivo, que aprove os têrmos de transferência ao Instituto, na forma da presente Lei, da responsabilidade a que se refere o artigo precedente, no que disser respeito a cada um dos Ministérios que possuírem ou devam possuir repartições de «estatística geral», $\mathrm{f}$ ca declarada a extinção dessa unidade na estrutura administrativa do Ministério e mais:

a) que o respectivo «serviço de estatíst ca geral» (criado ou a criar) se transfere ao I.B.E. como unidade descentralizada, mas continuará integrado no sistema de serviços do Ministério, e em estreita articulação com a totalidade das respectivas autoridades e dependênc as, as quais terão fácil acesso à competente documentação, e manterão o direito de prioridade quanto às informações no dominio das estatísticas de seu interêsse funcional, mesmo independentemente de se acharem estas publicadas;

b) qual o programa mínimo de pesquisas e levantamentos a ser executado para $\mathrm{f}$ ns das atividades técnico-administrativas do Ministério, de sorte que sejam levados em conta os regulamentos em vigor, os compromissos internos ou internacionais assumidos e as necessidades atuais do campo administrativo minister al.

c) que o Instituto ficará obrigado a fornecer os dados ainda inéditos, resultantes dos inquéritos especia s de que o Ministério eventualmente careça a juizo do Ministro; bem assim os dados, tão atualizados quanto possível e independentemente de prévia publicação, da «campanha nacional» em vigor, e relacionados com a competência m nisterial, utilizáveis nos relatórios anuais do Ministério, na forma que o Ministro determinar;

d) quais os quantitativos de exemplares, no que concerne às publicações do Instituto, de caráter geral ou referentes aos campos administrat vos jurisdicionados pelo Ministério, que devam ser entregues aos órgãos crmpetentes dêste;

e) que o Instituto se obriga a preparar a documentação gráfica especial, em original ou já impressa, conforme eventualmente carecer o Ministério, a critério do Ministro, inclusive para Exposições, Conferências Intergovernamentais (nacionais ou internac onais) e outros certames de que o setor ministerial participe;

f) que o Ministér o se obriga á franquear ao Instituto a pesquisa estatística nos seus arquivos ou nos acêrvos documentários das respectivas repartições; bem assim se compromete a reorganizar os seus registros sempre que se torne preciso para que sejam atendidos os interêsses da Estatística Geral do pais na conformidade da representação fundamentada que the fizer o Conselho Nacional de Estatística; e ainda o de realizar ou facilitar a realização (conforme o caso) das operações censitárias ou de amostragem se aprovadas pelo Ministro e relac onadas com as atividades do Ministério:

g) quais os atuais encargos da repartição transferida que tão se consideram de estatistica geral e qual o órgão ou quais os órgãos ministeriais a que tais encargos se transferem.

$\S 10^{\circ} \quad$ F cam igualmente autorizadas as delegações correlatas efetuadas pelos Estados e Territórios.

§ 2. ${ }^{\circ}$ Será dado novo Regulamento às unidades técnicas que como repartições autônomas passarem à jurisdição administrativa do Instituto Bra- 
sileiro de Estatística subord nadas diretamente ao Conselho Nacional de Estatística mas articuladas com a sua Secretaria-Geral conformemente às comdições gerais previstas nesta Lei.

Art. 56. Os cargos de diretor em comissão das «Repartições Centrais» do Instituto, ministeriais, estaduais ou territoriais, serão providos na forma desta Lei (art. 44). O provimento, porém além de fazer-se em comissão, só se efetivará mediante prévia aprovação da autoridade governamental sob cujos auspícios e vigilância tenha de operar cada uma das repartições em causa.

Art. 57. O atual Serviço Nacional de Recenseamento, de que trata o art. $3 .^{\circ}$ da Le: $n .^{\circ} 615$, de 13 de março de 1949 , funcionará em caráter permanente, passando a integrar, técnica e administrativamente, em adequada posição hierárquica, o quadro das «repartições centrais federais» do Instituto Brasileiro de Estatística.

Parágrafo único. O S.N.E. continuará com o encargo de concluir os trabalhos referentes ao VI Recenseamento Geral do Brasil, realizado em 1950 , observado no caso o Regulamento aprovado pelo Decreto $n .^{\circ} 26.914$, de 20 de julho de 1949.

Art. 58. Os titulares das carreiras de Estatístico e Estatístico-Auxiliar lotados nas respect vas repartições centrais de Estatística serão facultativamente transferidos para os quadros do Instituto Brasileiro de Estatística, respeitados os direitos e vantagens de que gozam, inclusive o da aposentadoria, nas bases fixadas pela Lei ${ }^{\circ}{ }^{\circ} 1.711$, de 28 de outubro de 1952 .

$\S 10^{\circ}$ Os servidores que optarem, dentro de trinta dias, a partir da promulgação desta Lei, pela não transferência, serão aproveitados $\epsilon \mathrm{m}$ outro cargo de carreira do mesmo nivel, no respectivo Ministério, a juizo do Poder Executivo, respeitados os direitos já adquir dos.

$\S 2 .^{\circ}$ Os servidores lotados nas repartições ora extintas e não integrantes das carreiras a que se refere êste artigo, serão redistribuidos por outras repartições do própr o Ministério, sèm prejuizo dos direitos adquiridos.

Art. 59. A fusão das carreiras transferidas por fôrça desta Lei, com as existentes no atual quadro da Secretaria-Geral do Conselho Nacional de Estatística, será feita respeitando-se a antiguidade de classe dos respectivos servidores e condicionada à constituição de um quadro único, sem excedentes nas classe de carreiras éstabelecidas.

Art. 60. Os níveis de remuneração dos servidores e dirigentes do Instituto Brasileiro de Estatística, bem como a reclassificação do padrão de seus cargos e carreiras, serão revistos pelo Poder Executivo, que fica autorizado a baixar o ato necessário para a sua efetivação, de conformidade com o que preceitua o art. 259, da Lei n. ${ }^{\circ} 1.711$, de 28 de outubro de 1952.

$\S 1 .^{\circ}$ Incluem-se nessa revisão os servidores transferidos por efeito da presente Lei.

$\S 2 .^{\circ}$ Continua em vigor o $\S 1 .^{\circ}$ do art. 11 do Decreto $n .^{\circ} 24.609$, de 6 de julho de 1934 . 
Art. 61. Fica aberto o crédito suplementar de Cr\$20.000.000,00 (vinte milhões de cruzeiros) em cada um dos exercícios de 1956, 1957 e 1958, para atender dentro do mesmo regime financeiro em que funciona o C.N.E., às despesas desta Lei que excederem o orçamento normal do Instituto, antes que estejam disponiveis os primeiros recursos do «Auxílio Convencional» único, na forma do disposto no $\S 7 .^{\circ}$ do art. 38 .

Parágrafo único. A êsses recursos se juntarão os que provierem da transferência ao Instituto dos saldos das competentes verbas, que existirem em cada Ministério ou Estado quando se fizer a transferência dos respectivos «órgãos centrais» de Estatística à administração do C.N.E.

Art. 62. As contas do I.B.E. continuam sujeitas ao exame do Tribunal de Contas da União, acompanhadamente do pronunciamento do $\mathrm{Co}$ légio Governamental do Conselho Nacional de Estatística.

Art. 63. Esta Lei entrará em vigor na data da sua publicação, revogadas as disposições em contrário.

Rio de Janeiro, 22 de novembro de 1955.

\section{SUMMARIO \\ I - Projeto DE LEI N. ${ }^{\circ}$}

(Dispõe sôbre a instituição e organização do "Concurso Teixeira de Freitas»; estabelece as bases da participação do Instituto Brasileito de Geografia e Estatistica, do Departamento Administrativo do Serviço Público, do Ministério da Educaçãa e Cultura e da Associação Brasileira de Municipios na realização conjunta do referido Concurso; autoriza a abertura de crédito especial e dá outras providências).

$$
\begin{gathered}
\text { II - Justificação } \\
\text { III - Documentação anexa }
\end{gathered}
$$

1. Discurso sôbre TeIXeIra de Freitas - Deputado Federal Josino Alves da Rocha Loures;

2. «Lei Pró-Municípios» - Teixeira de Freitas. 